\title{
Pro qualitate loci et instantia laboris: Monasteries and their Human and Natural Environments in Late Antique Gaul
}

\section{Matheus Coutinho Figuinha*}

Focusing on the cases of Martin of Tours' Marmoutier, the monastery of Lérins, and the Jura monasteries, this article explores the conceptions and interactions of Gallic monks with the human and natural environments in relation to their subsistence. Fourth- and fifth-century authors described these monasteries in similar terms, relying on both Christian and classical literary models. Accordingly, the local human and natural environments were depicted as characteristic of a remote desert. Archeologists, however, have shown that these monasteries were not isolated. One of the reasons for that, I argue, is that they depended on the contributions of visitors and on urban and commercial centers for their own existence. I also argue that, due to different conceptions of the monastic life and practice, monks' interactions with the human and natural environments varied greatly from one monastery to the other. At Marmoutier, Martin's disciples relied on the woodland nearby and on the Loire to get part of what they consumed. But because they did not practice manual labor, they may have acquired most of the necessary food from local farmers. At Lérins, where all the monks were required to work, it is possible that they practiced agriculture. But because of the restricted extension of the cultivated terrain and the Mediterranean climate, they did not produce all the food they consumed. As for the Jura monasteries, the monks deforested and cultivated large areas. They also reared cattle, poultry, and sheep, and constructed a mill and tilting hammers to grind grain. But their effort to sustain themselves only through the work of their hands was not enough, for they also relied on the Burgundian kings and pilgrims for their subsistence. The Jura monasteries in particular show us that the practice of agriculture is not per se evidence of economic autonomy.

Keywords: Gaul; human and natural environments; monasticism; Marmoutier; Lérins; Jura Fathers.

* Correspondence details: Matheus Coutinho Figuinha, Universidade Estadual de Campinas (UNICAMP), Departamento de História, Rua Cora Coralina, 100, Cidade Universitária Zeferino Vaz, 13083-896, Campinas/SP, Brazil. Email: figuinha@yahoo.com. 


\section{Introduction}

My purpose in this article is to investigate how late antique monks conceived and interacted with the human and natural environments in relation to their subsistence. I understand subsistence here as the obtainment of everything each monastery considered necessary for the monastic life, from food and clothes (that is, all that monks needed according to late antique authors, who intended to underline their austere discipline and material restrictions) to parchment. This article focuses on three case studies from Gaul, where there are both strong literary and archaeological sources: (1) Marmoutier, the monastery Bishop Martin founded close to the city of Tours around 372; (2) the monastery Honoratus founded on the island of Lérins, in the bay of Cannes, between 400 and $410 ; ;^{1}$ (3) the monasteries of Condat and Laucone, founded by Romanus and his brother Lupicinus in the Jura forests after 435 .

All these monasteries and the very distinct human and natural environments around them were similarly described as deserts, according to the model of saints' Lives and to classical literary traditions. However, different conceptions of the monastic life and practice from one monastery to the other led to different interactions with the human and natural environments. Even though monks invariably depended on the contributions of visitors and on the proximity to urban and commercial centers to acquire what they needed, their dependence varied according to what exactly they had to acquire and to what they could get in the nearby woodland (a constant presence) or produce locally.

\section{Martin of Tours' Marmoutier}

Martin was ordained as bishop of Tours in 371, but, according to his hagiographer Sulpicius Severus, he did not abandon his commitment to the monastic life: "There was the same humility in his heart, and the same vileness in his garments [...] in such a way as not to lay aside the resolution and virtues of a monk «. ${ }^{2}$ Martin initially established himself at a cell adjacent to the church of Tours, but sometime later, he founded a monastery two miles away from the city to avoid the disturbance of visitors. Sulpicius describes the monastery, the landscape around it, and the monks' discipline:

This spot was so secret and retired that he enjoyed in it the solitude of a hermit. For, on one side, it was surrounded by a precipitous rock of a lofty mountain, while the river Loire had shut in the rest of the plain by a bay extending back for a little distance; and the place could be approached only by one, and that, a very narrow passage. Here, then, he possessed a cell constructed of wood. Many also of the brethren had, in the same manner, fashioned retreats for themselves, but most of them had formed these out of the rock of the overhanging mountain, hollowed into caves. There were altogether eighty disciples, who were being disciplined after the example of the saintly master. No one there had anything which was called his own; all things were possessed in common. It was not allowed either to buy or to sell anything, as is the custom among most monks. No art was practiced there, except that of transcribers, and even

2 Sulpicius Severus, Vita sancti Martini, 10.2, ed. Fontaine, vol. 1, 272 and 274: "Eadem in corde eius humilitas, eadem in vestitu eius vilitas erat; atque ita, plenus auctoritatis et gratiae, inplebat episcopi dignitatem, ut non tamen propositum monachi virtutemque desereret«. Trans. Roberts, Life of St. Martin, 9, slightly adapted. 
this was assigned to the brethren of younger years, while the elders spent their time in prayer. Rarely did any one of them go beyond the cell, unless when they assembled at the place of prayer. They all took their food together, after the hour of fasting was past. No one used wine, except when illness compelled them to do so. Most of them were clothed in garments of camels' hair. Any dress approaching to softness was there deemed criminal, and this must be thought the more remarkable, because many among them were such as are deemed of noble rank. ${ }^{3}$

As Jacques Fontaine has pointed out, Sulpicius' description of the community Martin established and its surrounding landscape recalls not only the harshness of the monastic deserts represented by older saints' Lives and pilgrims' oral accounts, but also the symbolic language of the landscape depictions of the Aeneid. In joining these two literary models, Sulpicius intended both "to confer the inner dignity of a new scity of God to the setting of Marmoutier" and "to touch all learned readers", who certainly recognized and treasured his Virgilian borrowings. ${ }^{4}$ More recently, archeologists have been able to appreciate how far Sulpicius' stylized description distorted the human environment surrounding Marmoutier. Far from being a "secret and retired " place, the monastery could be easily accessed from the city. Nothing less than three wooden bridges connected the latter to the other bank of the Loire and one, constructed in the third century, still likely functioned when Martin founded the monastery. Sulpicius' "very narrow passage«, moreover, was actually a long, ancient road that passed through Marmoutier and that remained in use until the fourteenth century. ${ }^{5}$

As for Sulpicius' description of the monastery, in particular, Fontaine has already observed that the cliff still seen on the site was depicted as a "lofty mountain «, due to the symbolism of the mountain in the Bible and the Life of Anthony. ${ }^{6}$ However, archeologists have recently unearthed fragments and remains that indicate that the site was continuously occupied from the first century CE up to Martin's arrival. ${ }^{7}$ For the time being, it is impossible

3 Sulpicius Severus, Vita sancti Martini, 10.4-8, ed. Fontaine, vol. 1, 274: "Qui locus tam secretus et remotus erat, ut eremi solitudinem non desideraret. Ex uno enim latere praecisa montis excelsi rupe ambiebatur, reliquam planitiem Liger fluvius reducto paululum sinu clauserat; una tantum eademque arta admodum via adiri poterat. Ipse ex lignis contextam cellulam habebat, multique ex fratribus in eundem modum; plerique saxo superiecti montis cavato receptacula sibi fecerant. Discipuli fere octoginta erant, qui ad exemplum beati magistri instituebantur. Nemo ibi quicquam proprium habebat, omnia in medium conferebantur. Non emere aut vendere, ut plerisque monachis moris est, quicquam licebat; ars ibi, exceptis scriptoribus, nulla habebatur, cui tamen operi minor aetas deputabatur: maiores orationi vacabant. Rarus cuiquam extra cellulam suam egressus, nisi cum ad locum orationis conveniebant. Cibum una omnes post horam ieiunii accipiebant. Vinum nemo noverat, nisi quem infirmitas coegisset. Plerique camelorum saetis vestiebantur: mollior ibi habitus pro crimine erat. Quod eo magis sit mirum necesse est, quod multi inter eos nobiles habebantur, qui longe aliter educati ad hanc se humilitatem et patientiam coegerant [...] «. Trans. Roberts, Life of St. Martin, 9.

4 Fontaine, Sulpice Sévère. Vie de Saint Martin, vol. 2, 667-672. Cf. also de Vogüé, Histoire littéraire, vol. 4, 44, for other reminiscences.

5 Lorans, Aux origines du monastère, 179-184; id., Marmoutier, 60. I am very grateful to Professor Lorans for kindly sharing with me many of her publications.

6 Fontaine, Sulpice Sévère. Vie de Saint Martin, vol. 2, 669.

7 For all the archaeological discoveries, cf. Lorans, Aux origines du monastère, 196-200; Lorans and Creissen (ed.), Site 2013; id., Site 2014; id., Site 2015; id., Site 2016; Lorans, Marmoutier, 58-60; Lorans and Simon, Autour de Marmoutier, 88-91. 
to know exactly how such an occupation was. It may well have been, as Élisabeth Lorans has suggested, "a road station ${ }^{8}{ }^{8}$ In any case, there can be little doubt that Martin deliberately chose the site for the foundation of his monastery and that he, therefore, did not intend to be isolated. Quite the opposite. He wanted to maintain constant contact with the city - after all, he was the bishop - and with travelers passing by. ${ }^{9}$ He may also have taken advantage of the road network to which the monastery was connected to move in his campaigns of Christianization of the Touraine.

The ease of contact with the city and the countryside around it was crucial to the monastery's existence. In the Life of Saint Martin, Sulpicius narrates a telling episode:

On one occasion the devil, holding in his hand the bloody horn of an ox, rushed into Martin's cell with great noise, and holding out to him his bloody right hand, while at the same time he exulted in the crime he had committed, said: ,Where, O Martin is thy power? I have just slain one of your peopler. Then Martin assembled the brethren, and related to them what the devil had disclosed, while he ordered them carefully to search the several cells in order to discover who had been visited with this calamity. They report that no one of the monks was missing, but that one peasant, hired by them, had gone to the forest to bring home wood in his wagon. Upon hearing this, Martin instructs some of them to go and meet him. On their doing so, the man was found almost dead at no great distance from the monastery. ${ }^{10}$

According to Fontaine, the peasant was "a day laborer, foreign to the monastery «, for the expression mercede conducere, which in the passage characterizes how the peasant was hired, indicated since the time of Cicero the »temporary employment of modest people«. Because the monks did not practice manual labor, as Sulpicius attests in the tenth chapter of the Life, Fontaine concludes that they hired peasants to do some labors related to their »immediate material necessities «. ${ }^{11}$ However, the words "one of your people « attributed to the devil contradict Sulpicius' own use of mercede conducere and Fontaine's suggestion. They seem to reinforce Richard Goodrich's perception that the monastery possessed "servants or slaves" so that the monks did not need to practice manual labor. ${ }^{12}$

Lorans, Marmoutier, 59-60; Lorans and Creissen (ed.), Site 2017, 101; id., Site 2015-2017, 13; Lorans and Simon, Autour de Marmoutier, 91.

9 Lorans, Marmoutier, 60; Lorans and Simon, Autour de Marmoutier, 91.

10 Sulpicius Severus, Vita sancti Martini, 21.2-4, ed. Fontaine, 298 and 300: "Quodam autem tempore, cornu bovis cruentum in manu tenens, cum ingenti fremitu cellulam eius inrupit, cruentamque ostendens dexteram et admisso recens scelere congaudens: ubi est, inquit, Martine, virtus tua? unum de tuis modo interfeci. Tunc ille convocatis fratribus refert quid diabolus indicasset; sollicitos esse praecipit per cellulas singulorum quisnam hoc casu adfectus fuisset. Neminem quidem deesse de monachis, sed unum rusticum, mercede conductum ut vehiculo ligna deferret, isse ad silvam nuntiant. Iubet igitur aliquos ire ei obviam; ita haud longe a monasterio iam paene exanimis invenitur «. Trans. Roberts, Life of St. Martin, 14.

11 Fontaine, Sulpice Sévère. Vie de Saint Martin, vol. 3, 958-959.

12 Goodrich, Contextualizing Cassian, 193. 
It is not impossible that Sulpicius used the expression mercede conducere for literary embellishment, disregarding the precise relationship between the killed peasant and Marmoutier. Yet he had no reasons to use the expression knowing that the peasant belonged to the monastery. ${ }^{13}$ The same logic, however, holds for the words "one of your people « attributed to the devil: they may also be a literary stylization, intended to add drama to the account. Even though they may not be completely imprecise, it is anachronistic to assume, as Fontaine rightly reminds us, that the monks prayed cloistered in the monastery and that the works outside it were then ascribed to laymen. ${ }^{14} \mathrm{~A}$ middle ground would be to consider that Martin's disciples maintained recurrent contact with local peasants. In fact, we do not have any evidence that the former practiced agriculture or that Marmoutier owned land, so they probably had to acquire most of the food they consumed from local peasants. Given the importance of wood for cooking and heating, the latter may also have been hired much more frequently than Sulpicius indicates.

The forest quite certainly furnished Martin's disciples (and many other inhabitants of Tours) not only with wood, but also with food and other materials. ${ }^{15}$ A passage from Sulpicius' Dialogues indicates that the monks depended even on the Loire for food: "Being accustomed to eat fish at the time of Easter, he [Martin] enquired a little before the hour for refreshment, whether it was in readiness. Then Cato, the deacon, to whom the outward management of the monastery belonged, and who was himself a skillful fisher, tells him that no capture had fallen to his lot the whole day [...] «. ${ }^{16}$ Sulpicius continues the narrative saying that Cato, thanks to the miraculous intervention of Martin, was able to fish a "pike" (immanem isocem) that day. Martin and his disciples may well have eaten fish on days other than Easter. Considering Martin's question to Cato, Jacques Fontaine and Nicole Dupré have even envisaged the hypothesis that Marmoutier, similarly to Cassiodorus' Vivarium, had fishponds. ${ }^{17}$

If the monks did not buy the wine offered to the ill (Vita 10.7) from the peasants close to them, they bought it from merchants. The copyist job done by the younger monks also required papyrus, parchment, and other materials that needed to be acquired, not to mention the "garments of camels' hair" they wore (Vita 10.8). Martin and his disciples, therefore, had to maintain intense contact with the city not only because of the clerical duties some of them had, but also to get some of the products they consumed. Actually, since a road passed through the monastery, it was possible for them to acquire what they needed directly from merchants passing by. Their (or their fifth- and sixth-century successors') contact with city markets and merchants is corroborated by recent archaeological discoveries. Some fragments of ceramics and amphorae dated from the fourth to the sixth centuries and produced not only in Gaul, but also in North Africa and the East, have been brought to light.

On Sulpicius' reliability, cf. Fontaine, Sulpice Sévère. Vie de Saint Martin; Stancliffe, St. Martin and His Hagiographer. Fontaine, Sulpice Sévère. Vie de Saint Martin, vol. 3, 958-959.

15 Rothé, Carte archéologique, 139, has summarized the importance of forests for local inhabitants: "Sur le plan économique, la forêt constituait une ressource importante d'où tirait du bois (de chauffe, de construction ou pour la confection de meubles et/ou objets), de la résine, de la poix, des fruits sauvages, mais également du gibier qui trouvait son alimentation dans les forêts de feuillus (altitude inférieure à $800 \mathrm{~m}$ )《.

16 Sulpicius Severus, Dialogi, 3.10.1-2, ed. Fontaine and Dupré, 328: „Piscem Paschae diebus edere consuetus, paulo ante horam refectionis interrogat an haberetur in promptu. Tum Cato diaconus, ad quem monasterii administratio pertinebat, doctus ipse piscari, negat per totum diem sibi ullam cessisse capturam [...]«. Trans. Roberts, Dialogues, 50.

17 Fontaine and Dupré, Sulpice Sévère. Gallus, 324, n. 7. 
Other fragments have even suggested that, in the fifth and sixth centuries, monks were involved in craftwork (metallurgy and tabletterie work), which could have been a source of income for them and could have then intensified their contacts with markets and merchants. ${ }^{18}$

It is likely, however, that this artisanal production was not carried out at the time of Martin, for Sulpicius said - and that sounds indeed like a Martinian precept - that monks could not engage in craftwork (ars) and lucrative activities; instead, they (except the younger ones) should stay in their cells praying. ${ }^{19}$ Because of such instructions, scholars tend to suppose that the monetary resources of Marmoutier came from the properties possessed by the "many nobles « mentioned by Sulpicius in the tenth chapter of the Life.$^{20}$ However, only two disciples of Martin (Clarus and Gallus) seem to have come from local aristocratic families. Furthermore, a passage from Sulpicius' Dialogues contradicts the impression that the monastery depended on the properties of wealthy monks:

He [Lycontius] also offered a hundred pounds of silver, which the blessed man neither rejected nor accepted; but before the amount of money touched the threshold of the monastery, he had, without hesitation, destined it for the redemption of captives. And when it was suggested to him by the brethren, that some portion of it should be reserved for the expenses of the monastery, since it was difficult for all of them to obtain necessary food, while many of them were sorely in need of clothing, he replied, 'Let the church both feed and clothe us, as long as we do not appear to have provided, in any way, for our own wants.$^{21}$

Martin's disciples would not have faced destitution if they could count on the resources of many nobles' properties.

Relying on this passage, some scholars have alternatively argued that Martin's reply to the monks indicates that it was the church of Tours that sustained Marmoutier. ${ }^{22}$ There is no reason to question such an assumption, but we must not overlook the allusions to contributions

18 For all the archaeological discoveries and their possible implications for our understanding of the monks' practices, cf. Lorans and Creissen (ed.), Site 2015; id., Site 2016; Lorans, Marmoutier, 63-64; Lorans and Creissen (ed.), Site 2017; id., Site 2015-2017; Lorans and Simon, Autour de Marmoutier, 91.

19 Bord, Aux origines du monachisme, 19. Some scholars have considered these instructions an influence of Messalianism, known by Martin through Hilary of Poitiers, his spiritual master, who remained exiled in Phrygia between 356 and 360. Cf. Sulpicius Severus, Chronica 2.42.1, ed. de Senneville-Grave, 322; Gribomont, Influence du monachisme oriental, 137; Stancliffe, St. Martin and His Hagiographer, 260-261; Fontaine and Dupré, Sulpice Sévère. Gallus, 70. This view, however, is disputed. De Vogüé, Histoire littéraire, vol. 4, 47-48, argues that Martin was influenced instead by Eusebius of Vercelli, and Caner, Wandering, Begging Monks, 125, n. 191, suggests that "more likely Martin found his precedents in the Gospels and Acts«. In any case, Martin should not be seen as being in opposition to eastern monasticism. The ideal that monks should practice manual labor in order to overcome acedia and to sustain themselves or their communities became predominant in Egypt only at the end of the fourth century; and yet Messalianism and other monastic lifestyles that favored continuous prayer and begging remained diffuse in the East (even in Egypt) until much later. On this issue, cf. Caner, Wandering, Begging Monks.

20 Since the appearance of Fontaine, Sulpice Sévère. Vie de Saint Martin. I have already examined the supposed presence of "many nobles« at Marmoutier and the sources of income of the monastery in Figuinha, Monasticismo; id., Subsistence.

21 Sulpicius Severus, Dialogi, 3.14.5-6, ed. Fontaine and Dupré, 346: „Centum etiam argenti libras obtulit, quas vir beatus nec respuit nec recepit; sed priusquam pondus illud monasterii limen adtingeret, redimendis id captivis continuo deputavit. Et cum ei suggereretur a fratribus ut aliquid ex eo in sumptum monasterii reservaret - omnibus in angusto esse victum, multis deesse vestitum: `Nos, inquit, ecclesia et pascat et vestiat, dum nihil nostris usibus quaesisse videamur«. Trans. Roberts, Dialogues, 52.

22 Cf. most recently de Vogüé, Histoire littéraire, vol. 4, 47-48 and 146-147. 
from devotees. Lycontius' generous donation would have been brought to the monastery if Martin had not destined it for another purpose. Finally, the monks who were consecrated as clerics provided alternative revenue as they received wages from the Church. ${ }^{23}$ We can only understand how the monk-priest Brice could buy horses and slaves for himself if he received a salary, for he did not possess anything before being a cleric. ${ }^{24}$

\section{The monastery of Lérins}

At the end of 427 or the beginning of 428 , Honoratus, founder of the monastery of Lérins, in the bay of Cannes, was consecrated as bishop of Arles. ${ }^{25} \mathrm{He}$ departed for the city accompanied by Hilary, a younger relative who had also established himself at Lérins. Due to his "love of the desert «, however, Hilary rejoined the monastery some months later. ${ }^{26}$ Yet he was not sure of his decision. Honoratus sent letters asking him to return to Arles, ${ }^{27}$ but he, in his turn, requested the opinion of others. It is in response to one of his letters that Eucherius, a fellow monk of Lero, the largest of the Lérins islands in the bay of Cannes, composed the Praise of the Desert. Trying to persuade Hilary to stay at Lérins, Eucherius argued that deserted and isolated places, as Lérins supposedly was, were privileged because of their proximity to God. ${ }^{28}$

As Eucherius claims in chapters 39-41, one of the privileges of the desert was the abundance and fertility it offered. Its inhabitants, according to him, could earn "numerous products and a hundred fruits ". ${ }^{29}$ Leaning on the parable of the sower (Matthew 13.4-7; Mark 4.3-7; Luke 8.5-7), he asserts that the seeds thrown there hardly fall on the path, where they would be eaten by birds, or on rocky soils, where they would be dried by the sun, or among thorns, where they would be prevented from growing. And he adds:

The colonus will reap there an abundant-yield harvest and in these rocks it is produced that fruit through which even bones grow fat. It is also found in there sthe living bread that came down from the sky< (John 6.51), and overflowing springs and living waters, which can satisfy not only those who need to quench their thirst, but also those who need to be saved, burst forth from those cliffs. Here is the meadow and delight of the interior man, here is the uncultivated desert, but there is the pleasure of wonderful loveliness, at the same time desert of the body and paradise of the soul. ${ }^{30}$

23 De Vogüé, Histoire littéraire, vol. 4, 147.

24 Sulpicius Severus, Dialogi, 3.15.2, ed. Fontaine and Dupré, 350. We cannot know, however, if the charges are really true, for Sulpicius is clearly trying to defame Brice.

25 On the date, cf. Chadwick, Euladius of Arles.

26 Eucherius, De laude eremi 1.1-5 and 44.1, ed. Pricoco, 134, 136, and 184; Hilary, Sermo de vita sancti Honorati 36.2, ed. Valentin, 168.

27 Hilary, Sermo de vita sancti Honorati 36.2, ed. Valentin, 168.

28 Eucherius, De laude eremi 3.2, ed. Pricoco, 138; Leyser, »This Sainted Isle«, 196. On the development of the idea of the monastic desert in the West, cf. Markus, End, 157-211.

29 Eucherius, De laude eremi 39.2, ed. Pricoco, 176: "Illic multiplex germen et centenos accola fructus recondit«.

30 Eucherius, De laude eremi 39.3-5, ed. Pricoco, 176 and 178: »Uberi illic messem proventu colonus metet, producitur in his saxis seges illa per quam etiam ossa pinguescunt. Invenitur etiam illic spanis vivus qui de caelo descendit، (Io 6.51), erumpunt in illis rupibus fontes irrigui et aquae vivae, quae non satiandis solum, verum etiam possint sufficere salvandis. Hic interioris hominis pratum et voluptas, hic incultum desertum, illic mira amoenitate iocundum est, eademque corporis est eremus, animae paradisus«. Unless indicated otherwise, the translations are those of the author. 
Eucherius continues his description of the fertility of the desert stating that no other land could produce as much food: in there, "that wheat which satiates the hungry with its nutrients grows exceedingly«. Vineyards were more abundant: in there, "that wine which fully scheers men's heart` (Psalm 103.15) is produced exceedingly«. Pastures were unparalleled: in there, "those sheep about which it is said: >Pasture my sheep (John 21.17) pasture in the most salutary manner ". Flowers were more colorful: in there, "that true swild flower and lily of the valley< (Song of Songs 2.1) shines exceedingly". And there were also copious quantities of precious metals and gold: in there, »the many splendors of gems shine with vibrant light«. For Eucherius, therefore, the desert offered much more wealth than any other land. ${ }^{31}$

Some scholars have read Eucherius' words on the fertility of the desert as a description of the natural resources of Lérins, which had supposedly been transformed by the Lerinians since Honoratus' arrival..$^{32}$ It has even been suggested that the "natural riches of the island" described by Eucherius were precisely one of the factors that prompted the monastery to become an autonomous villa in less than three decades. ${ }^{33}$

It is important to note, however, that Eucherius' description of the fertility of the desert does not refer to Lérins. He starts to deal with the island only in chapter 42, when he writes: "I truly own reverence to all desert places which are illuminated by the retirement of pious men, but I embrace my Lérins with special honor «. ${ }^{34}$ This sentence indeed indicates a clear change of subject: from desert places in general he moves to Lérins in particular, with which he will deal (chapters 42-43) until the conclusion of the work (chapter 44). ${ }^{35}$

Eucherius' words in chapters 39-41, moreover, are not to be read literally. They are allegorical, for the fertility of the desert is purely spiritual. ${ }^{36}$ As Manté Lenkaityté has pointed out, the key to understanding these chapters (39-41) of the Praise of the Desert is another work composed by Eucherius himself, the Formulae of Spiritual Knowledge, in which he presents an allegorical meaning to terms of the Bible. The harvests are said to be "the abundance or the multitude of the faithful " (Messis ubertas vel copia fidelium); the bread suggests "Christ or the word of the Lord " (Panis Christus vel sermo domini); the meadows recall »the enjoyment of a progressing soul" (Herbae iucunditas quaedam proficientis animae); the wheat recalls "the saints or the elected of God" (Triticum sancti vel electi dei); the vineyard symbolizes

31 Eucherius, De laude eremi 40.1-5, ed. Pricoco, 178: "In hac maxime nascitur frumentum illud, quod esurientes adipe suo satiat. [...]. In hac maxime profertur vinum illud, quod bene slaetificat cor hominis` (Ps 103.15). [...]. In hac saluberrime pascunt oves illae, de quibus dicitur: >Pasce oves meas` (Io 21.17). [...]. In hac maxime verus ille sflos campi et lilium convallium ‘ (Ct 2.1) refulget. [...]. In hac varii lapidum micant vibrante luce fulgores".

32 Kasper, Theologie und Askese, 80; Rousseau, Cassian: Monastery and world, 72; Heijmans and Pietri, "Lobby« lérinien, 54.

33 Nouailhat, Saints et patrons, 223-225.

34 Eucherius, De laude eremi 42.1, ed. Pricoco, 180: "Equidem cunctis eremi locis quae piorum illuminantur secessu reverentiam debeo, praecipuo tamen Lirinum meam honore complector [...]

35 De Vogüé, Histoire littéraire, vol. 7, 94-95.

36 Pricoco, Isola dei santi, 163-164; de Vogüé, Histoire littéraire, vol. 7, 93-95; Lenkaityté, Eucher; Pricoco, Eucherio. Elogio dell'eremo, 64 and 307-312. On p. 313, however, Pricoco supposes that "Senza dubbio, descrivendo gli aspetti dell'eremo monastico ed esaltando le virtù dei suoi asceti, lo scrittore ha avuto nella mente e negli occhi il modello lerinese« (cf. also p. 46). 
"the church or the people of Israel «(Vinea ecclesia vel populus Israhel); the pasture represents "the spiritual refection " (Pascua refectio spiritalis); the flowers evoke »Christ or the ornament of justice" (Flores Christus vel specimen iustitiae); and the gems "occasionally are Christ or the saints" (Lapides interdum Christus aut sancti) or even "the apostles, the saints or the own works of virtue " (Lapides pretiosi apostoli vel sancti sive ipsa opera virtutum) ${ }^{37}$ Lenkaityte then concludes: "The gracious image of the desert is not a simple locus amoenus, a literary topos. In the author's thought, this nice image encompasses a more profound meaning, anchored in Scripture: the Christian community within the church, nourished by God's word and on the way to the Lord «. ${ }^{38}$

Eucherius did not intend to show, consequently, that the desert offered material wealth to its current inhabitants, the monks. In that location, they could obtain only spiritual wealth. Chapter 41 leaves no doubt as to the spiritual meaning, and spiritual meaning only, of the fertility of the desert: "Therefore, you rightfully presented yourself, venerated land, as inhabitable or desirable to the saints who have been placed in you or removed not far from you, because, in exchange of all goods, you are fertile of him in whom everything is possessed «. ${ }^{39}$ There is a clear opposition here between the material poverty of the desert and its spiritual wealth and such an opposition is consequential: the desert can only be fertile of God because it does not have any material goods.$^{40}$ That is why Eucherius says that the "desert of the body « is the "paradise of the soul«. His only purpose in chapters 39-41, therefore, was to deal with the spiritual advantages that the desert supposedly offered to monks.

As Eucherius starts to deal with Lérins in chapter 42, he presents the nature of the island: "Gushing with waters, green with vegetation, shining with flowers, pleasant to the sight and the smell, it shows to those who possess it the paradise which they will possess «. ${ }^{41}$ In this passage, Eucherius clearly borrows from the literary tradition of the locus amoenus, ${ }^{42}$ but he also associates with Lérins, through a repetition of elements, the spiritual fertility of the desert he enumerates in chapters 39-41. However, we cannot confuse the allegorical fertility of the abstract desert and of Lérins with the actual nature of the island. Eucherius certainly felt affection for Lérins and alluded to elements that Hilary could see on it, but he did not intend to offer a realistic description of its nature. ${ }^{43}$ His purpose was to simply pinpoint those

37 Lenkaityté, Eucher, 97-98.

38 Lenkaityté, Eucher, 98.

39 Eucherius, De laude eremi 41.1, ed. Pricoco, 178: »Recte ergo tu, veneranda tellus, sanctis aut in te positis aut non procul a te remotis aut habitabilis dudum aut desiderabilis exstitisti, quia pro universis bonis illius es fertilis, in quo habentur universa«.

40 De Vogüé, Histoire littéraire, vol. 7, 97.

41 Eucherius, De laude eremi 42.2, ed. Pricoco, 180: „Aquis scatens, herbis virens, floribus renitens, visibus odoribusque iocunda, paradisum possidentibus se exhibet quem possidebunt [...]«.

42 Rapp, Desert, city, and countryside, 109.

43 Pricoco, Isola dei santi, 164. 
elements that had a spiritual meaning for him, a meaning he had just indicated in chapters 39-40, in order to demonstrate to Hilary that the "desert" of Lérins was the best place for a monastic life. Therefore, Eucherius did not contemplate, as some scholars have thought, the transformations of the island performed by the monks. ${ }^{44}$ Actually, Lérins' nature appears paradisiac in the passage precisely because it is still inviolate.

In a kind of "reply to Eucherius«, preached in 431 as a sermon to the community of Arles to commemorate one year of Honoratus' death, Lérins is depicted in a very different fashion..$^{45}$ Before Honoratus landed on the island, it was a wild and hostile place, »uninhabited because of the excess of squalor and unapproachable because of the fear of poisonous animals«. ${ }^{46}$ According to Hilary, Lérins was a »terrible desert « (terribilem illam vastitatem), an "arid place" (in illis ariditatibus), dominated by »the obscurity of a previously unknown exile" (ignoti prius exilii obscuritas). It was only with Honoratus' arrival that it was transformed in a way that it became illuminated by "the works of angels «. ${ }^{47}$ He made the "horror of the desert « disappear and the "crowd of serpents « that lived on the island go away. ${ }^{48}$ Even the abundant spring there was the result of a Honoratus' miracle. ${ }^{49}$

Hilary's account is not more reliable than Eucherius', for his Lérins is also romanticized following other common tropes. He emphasized the contrast of the desolated Lérins before Honoratus to the angelic Lérins after him in order to praise his charisma and holiness. ${ }^{50}$ Concerning the foundation of the monastery and its maintenance, Hilary is quite vague. He only states that Honoratus built a church and habitations for the monks, and that the community grew quickly, receiving postulants from many places. ${ }^{51}$ He also says that Honoratus saved from the donations of the faithful only what was necessary for their daily food and clothes. All the rest he donated to the poor and for the release of prisoners..$^{22}$ But here, again, Hilary intended to celebrate Honoratus. He would have been so detached from the material world that he had not only disposed of all his possessions, following Matthew 19.21, but also distributed to the poor the huge amount of money donated by pilgrims, following Biblical and monastic precepts to do charity. ${ }^{53}$

44 Nouailhat, Saints et patrons, 223-225; Pricoco, Eucherio. Elogio dell'eremo, 314, though he recognizes "una sicura valenza allegorica« to the passage (cf. also p. 46).

45 Leyser, »This Sainted Isle«, 197-200. This whole paragraph depends on Leyser's reading of Hilary's Sermo.

46 Hilary, Sermo de vita sancti Honorati 15.2, ed. Valentin, 108: "Vacantem itaque insulam ob nimietatem squaloris et inaccessam venenatorum animalium metu [...] .

47 Hilary, Sermo de vita sancti Honorati 16.1, ed. Valentin, 110.

48 Hilary, Sermo de vita sancti Honorati 15.4, ed. Valentin, 110.

49 Hilary, Sermo de vita sancti Honorati 17.1, ed. Valentin, 112 and 114.

50 On Hilary's purposes in the Sermo, cf. Leyser, »This Sainted Isle«; Natal, »A Suitable Successor«.

51 Hilary, Sermo de vita sancti Honorati 17.1, ed. Valentin, 112; 20.4 and 19.1, ed. Valentin, 128 and 124.

52 Hilary, Sermo de vita sancti Honorati 20.4, ed. Valentin, 128.

53 Hilary, Sermo de vita sancti Honorati 20.3-4, ed. Valentin, 126 and 128. 
In their works, Eucherius and Hilary were not interested in the growth of the monastery. ${ }^{54}$ But we know from John Cassian that it became a "great monastery of brothers " shortly before Honoratus left for Arles. ${ }^{55}$ At that time, it may have gathered one hundred monks or more.$^{56}$ The change in the work regime from the Rule of the Four Fathers, written between 414 and $419,{ }^{57}$ to the Second Rule of the Fathers, composed when Honoratus was ordained as bishop,,$^{58}$ also indicates that the monastery grew. The Rule of the Four Fathers, whose composition was very much influenced by Egyptian monasticism, ${ }^{59}$ determined that monks should dedicate themselves to reading from the first hour to the third and to manual labor from the third hour to the ninth. ${ }^{60}$ The Second Rule of the Fathers also prescribed reading until the third hour and manual labor from the third to the ninth, but it stipulated that reading should be put aside if there was something to do for the community. ${ }^{61}$

The growth of the monastery and the requirement of manual labor can be seen as indications that Lerinians practiced agriculture on the island..$^{62}$ In a homily, however, Faustus asserted that Maximus, Honoratus' successor as abbot, had once hidden in the »dense wood" of Lérins for three whole days, during which he was sought by an "invading multitude of faithful« from Fréjus who wanted him to be consecrated as bishop of the city. ${ }^{63}$ For Maximus to be able to do that, most of the island still had to be covered by a wood. A study of the charcoal found in a fire pit directly associated with the remains of an architectonic structure from the second half of the fifth century excavated under the Saint-Sauveur chapel seems to corroborate this impression, for it shows precisely the burning of tree species that existed on Lérins. ${ }^{64}$ In fact, a "dense wood « allows us to better understand the presence on a small and plain island of »those old saints", in Eucherius' words, "who in separated cells brought to our Gauls the Egyptian Fathers «. ${ }^{65}$ If we assume that Lerinians practiced agriculture, we need also to assume, therefore, that they deforested and cultivated only a small part of the island. It was much more important for their survival to have a wood close by (because of wood, and perhaps food and other products) than to cultivate the whole island.

54 Leyser, »This Sainted Isle«, 189, 192, and 205.

55 John Cassian, Conlationes 11-17, preface, ed. Pichery, 98. Cf. Pricoco, Isola dei santi, 40-41.

56 Nouailhat, Saints et patrons, 236-237; Figuinha, Economy.

57 Figuinha, Data.

58 De Vogüé, Règles, 209-266.

59 De Vogüé, Règles, 55-205.

60 Regula quattuor patrum 3.10-11, ed. de Vogüé, 194.

61 Secunda regula patrum 23-25, ed. de Vogüé, 278.

62 The monastery of Lérins is presented as a productive villa by Nouailhat, Saints et patrons, 234-238; Brown, Through the Eye, 420; Alciati, Sistema agricolo familiare, 134-135.

63 Eusebius Gallicanus, Homilia 35.8, ed. Glorie, 407.

64 Gillot and Codou, Témoin.

65 Eucherius, De laude eremi 42.3, ed. Pricoco, 182: »[...] sanctos senes illos, qui divisis cellulis Aegyptios patres Galliis nostris intulerunt«. See also Secunda regula patrum 30, ed. de Vogüé, 280. Archaeological excavations conducted by Yann Codou under the chapel of Saint-Sauveur brought to light remains of a church and a building that may have been occupied by a hermit or a group of them. Cf. Codou, Île Saint-Honorat; id., Aux origines du monachisme en Gaule; id., Aux origines du monachisme. 
Concerning the amount of food Lerinians could have produced, we need to consider not only the extent of the cultivated land, but also the effect of the Mediterranean climate. Peregrine Horden and Nicholas Purcell have shown that none of the microregions that formed the basin of the Mediterranean - and Lérins may be considered one of them - was independent from the others. Because the climatic and geographical conditions of a microregion were in constant change, what could be cultivated in one year could not be cultivated in the next. The inhabitants of each microregion, consequently, had to maintain an intense interaction between them. They needed to import what they had not been able to produce and export what they had in excess. ${ }^{66}$

But Lerinians did not need only food and clothes for their subsistence, as Hilary stated. We know from their writings that the monastery had a great library, ${ }^{67}$ and because the Rule of the Four Fathers instituted three hours of reading, ${ }^{68}$ those who did not know how to read - perhaps some of the "wild beasts " of barbaric origin transformed into "gentle doves « by Honoratus in Hilary's Sermon, or some of the poor mentioned by the Rule of the Four Fathers - had to learn. ${ }^{69}$ Eucherius' sons, Salonius and Veranus, who arrived still very young, were educated on the island. ${ }^{70}$ It all means that Lerinians had to acquire wax, papyrus, parchment, and other materials.

To do that, they depended on the land and maritime routes that connected the island to the nearby continent and commercial centers of the Mediterranean. ${ }^{71}$ These links underscore that Lérins was not an isolated desert as Eucherius and Hilary portrayed it. Even though it had not been inhabited before Honoratus, it had been visited regularly: archaeological research has identified a range of objects and fragments that date from the first to the second half of the fourth century. ${ }^{72}$ Pliny says that Lérins had once had "a town called Berconum «, ${ }^{73}$ but that town was most likely situated at Lero, which he also mentions, located less than half a mile north of Lérins. For Lero, indeed, seems to have been continuously occupied from the third century BCE to the fifth century CE. Strabo says that Lero had a colonial settlement and a sanctuary dedicated to Lero, ${ }^{74}$ and archeologists have discovered not only fragments and remains that corroborate the existence of Strabo's sanctuary, possibly erected in the sixth century BCE, and perhaps of Pliny's town, possibly built in the third century BCE, but also

66 Horden and Purcell, The Corrupting Sea.

67 The classic text is Courcelle, Nouveaux aspects. Cf. more recently Kasper, Theologie und Askese, 14-18; Dulaey, Bibliothèque; Gioanni, Culture profane. These authors have identified more than one hundred classical and ecclesiastical works quoted by the Lerinians, works that they quite likely had at their disposal on the island.

68 Regula quattuor patrum 3.10, ed. de Vogüé, 194; de Vogüé, Règles, 131-135.

69 Hilary, Sermo de vita sancti Honorati 17.4, ed. Valentin, 114; Regula quattuor patrum 2.18-28, ed. de Vogüé, 188 and 190.

70 Pricoco, Isola dei santi, 47; Pietri and Heijmans, Prosopographie chrétienne, vol. 2, 1685 and 1926.

71 Nouailhat, Saints et patrons, 143-144, has already called attention to this point.

72 Statues of pagan gods, funerary, military, and votive inscriptions, as well as sarcophagi. The origin of these objects and fragments, however, is not completely certain. On all of them, cf. Codou, Les îles de Lérins, 279-282.

73 Pliny, Naturalis historia 3.5.79, ed. LCL 352, 58: "[...] Lero et Lerina adversum Antipolim, in qua Berconi oppidi memoria«. Trans. Rackham, 59.

74 Strabo, Geographikon 4.1.10, ed. LCL 50, 191. 
remains of other buildings and complexes. There were on the island a sanctuary dedicated to Pan, honorific walls dated from the time of Augustus, a sophisticatedly decorated complex from the beginning of the first century $\mathrm{CE}$, a thermal complex, and perhaps a villa, of which the thermal complex may have been part. There are also attestations of a building that was adapted at the end of the fourth century CE to become a furnace for ceramics and that was used until the mid-fifth century, and of an artisanal complex (zone artisanale). Moreover, archeologists have found ceramics from Italy, Gaul, and Africa, amphorae from Chios, Italy, Gaul, Baetica, and Africa, and many other objects associated with some of these structures. ${ }^{75}$

All these archaeological objects and remains show that there were sailing routes that connected both islands to Cannes (a North-South route) and to Italy, Marseille, Arles, Narbonne, and Spain (an East-West route). Indeed, the Itinerary of Antoninus mentions Lero and Lérins as a stop between Antibes and Fréjus. ${ }^{76}$ The workers and other inhabitants of Lero consumed food, clothes, tools, and other products that could be brought from the nearby continent or from an important commercial center like Marseille (a little more than one hundred miles from Cannes). At the same time, the objects produced at Lero needed to reach commercial centers or other destinations, and transport could be directly by the sea or, reaching the nearby continent, by land.

Hilary alludes to the insertion of Lérins into these land and maritime routes when he says that Honoratus once came back home just to take him to the island. ${ }^{77}$ Honoratus may have gone to Cannes or even Fréjus by boat and then reached his patria through land routes. Many pilgrims also came to Lérins just to see Honoratus. Hilary rhetorically asked his community in Arles: "Who did not gladly interrupt a prosperous navigation or favorable winds, despising his own advantage, in favor of the desire to meet so great a man? Or who did not evaluate a powerful thrust favorable to navigation as the most violent storm if he could not land on the island? « $^{78}$ Prisoners redeemed by Honoratus also came "from diverse regions " to Lérins ${ }^{79}$ and the poor stopped by to receive his generous donations. According to Hilary, Honoratus once donated the only gold coin remaining (out of other donations) to a "passing poor man ${ }^{80}{ }^{80}$ People came to Lérins, moreover, to deliver mail, to which Honoratus answered with "gravity, charm, and sweetness «. ${ }^{81}$

Hilary certainly exaggerated the amount of pilgrims, poor people, and mail coming to Lérins, again, to praise Honoratus. However, the monastery established intense contact with the Christian community of many cities of Gaul. It was under the jurisdiction of the church of Fréjus and, thanks to the literary and theological skills of some of its monks, it became an intellectual and spiritual center. The contact of the monastery with other cities is indicated

75 For all the archaeological findings, cf. Codou, Les îles de Lérins, 269-279. According to him, some remains even attest »une occupation de la fin du Néolithique, du Bronze moyen et de tout l'âge du Fer« (p. 271). One wonders how Eucherius' and his wife's settlement on Lero may have been. Could they be the owners of some of the structures that existed on the island?

76 Itinerarium provinciarum Antonini Augusti 504-5-505.1, ed. Parthey and Pinder, 246-247.

77 Hilary, Sermo de vita sancti Honorati 23.2, ed. Valentin, 132 and 134.

78 Hilary, Sermo de vita sancti Honorati 20.1, ed. Valentin, 126: »Quis non quamlibet prosperam navigationem, quamlibet secundos ventos mox pro tanti viri desiderio commodi sui contemptor abrupit aut, si insulam tenere non licut, violentum secundae navigationis obsequium acerbissimam tempestatem computavit?«.

80 Hilary, Sermo de vita sancti Honorati 21.1, ed. Valentin, 128.

81 Hilary, Sermo de vita sancti Honorati 22.1, ed. Valentin, 130: "[...] quam gravia, quam blanda, quam dulcia!«. 
mostly by the fact that many of its members were ordained bishops: Honoratus and Hilary in Arles, Maximus and Faustus in Riez, Lupus in Troyes, Eucherius in Lyon, Salonius in Geneva, Venantius in Vence, and Antiolus in an unknown city. ${ }^{82}$ Devotees from these and other Christian communities, therefore, may have come regularly to Lérins to meet the monks, traveling via the land and maritime routes that connected the island to big cities and commercial centers. It was on these same routes that Lerinians depended to get what they consumed.

The money to spend on what they needed came from different sources. ${ }^{83}$ Scholars suppose that money and all the stuff they consumed on the island came either from the practice of manual labor or from the land properties that wealthy postulants offered to the monastery ${ }^{84}$ The Rule of the Four Fathers and the Second Rule of the Fathers, indeed, established manual labor for all the monks. However, there is no evidence that they were able to procure all they consumed only through their work or that the sale of what they produced was enough to buy all they lacked. Not even Egyptian monks, who were so highly praised by Cassian and other writers of the time for their discipline to manual labor, were able to do so ${ }^{85}$ As for properties, monks were formally allowed to offer part of their wealth to the community since the composition of the Rule of the Four Fathers. ${ }^{86}$ But none of the Lerinians' Lives that came down to us attest donations to the monastery. ${ }^{87}$ We may, then, suppose that the majority of the donations were actually movable property ${ }^{88}$

Despite Hilary's overestimation of donations to Honoratus, it is quite possible that they partially contributed to the maintenance of the monastery. But most of the monks' resources came from the church of Fréjus. In the Arrangements of the third council of Arles, gathered between 449 and 461, the bishops requested Theodorus of Fréjus, »as befits a former abbot and bishop, to perpetually send the pious and necessary contribution to him [Faustus, abbot of Lérins at the time], and to fully send the corresponding relief, which he deigned to promise in words, to those things that necessity demands « ${ }^{89}$ Most probably, the church of Fréjus contributed to the Lerinians' subsistence since the beginning. Not only was the monastery under its jurisdiction, but also, Honoratus decided to establish himself at Lérins to be close to Leontius, Theodorus' predecessor..$^{90}$

82 On all of them, cf. Pietri and Heijmans, Prosopographie chrétienne.

83 I have examined this question with more detail in Figuinha, Economy.

84 From manual labor: Quacquarelli, Lavoro e ascesi, 63; Labrousse, Origines, 68. From land properties: Pricoco, Isola dei santi, 119-120; Nouailhat, Saints et patrons, 238-244; Brown, Through the Eye, 413-417 (who suggests that the monastery was also sustained by the donations of wealthy laymen, to whom Lerinians were connected either by blood or by intellectual culture); Pricoco, Eucherio. Elogio dell'eremo, 45.

85 Wipszycka, Aspects économiques.

86 Regula quattuor patrum 2.34, ed. de Vogüé, 190.

87 On Hilary: Eucherius, De laude eremi 3.1, ed. Pricoco, 138; Honoratus of Marseille, Vita sancti Hilarii 6, ed. Jacob, 102. On Honoratus: Hilary, Sermo de vita sancti Honorati 11.4, ed. Valentin, 98 and 100. On Maximus: Eusebius Gallicanus, Homilia 35.2, ed. Glorie, 402. On Lupus: Vita sancti Lupi episcopi 3, ed. Krusch, 296.

88 Regula quattuor patrum 2.35, ed. de Vogüé, 190 and 192, allowed monks to bring some of their slaves to the monastery, but as long as the former considered the latter their brothers. This topic is treated right after that of the donations.

89 Institutio sanctorum episcoporum in causa insulae Lerinensis 17-20, ed. Munier, 133: "Quin potius collationem, utpote antiquus abba et episcopus, ei ut piam ac necessariam perpetuo exhiberet et solacia secutura, quae verbis dignabatur promittere, rebus ipsis in quo usus exigeret plenissime exhiberet«. Trans. Figuinha, Economy.

90 Hilary, Sermo de vita sancti Honorati 15.2, ed. Valentin, 108. 


\section{The Jura monasteries}

Between 512 and 514, an anonymous author composed the Life of the Jura Fathers at the request of John and Armentarius, members of a monastery next to the shrine of Saint-Maurice, in Agaune. ${ }^{91}$ The text presents a history of the monasteries of Condat and Laucone, in the Jura forests, through the biography of their founders, Romanus and his brother Lupicinus, and of their disciple and successor as abbot Eugendus. The author of the Life was himself a monk of Condat and disciple of Eugendus, and his account is detailed and, most of the time, reliable. ${ }^{22}$ That is why the text has been recently considered as "one of the most consistent sources that we have on western monasticism before Saint Benedict $"{ }^{93}$ For scholars dealing with post-Benedictine monasticism, it can appear as an odd text, for it does not present a rich and powerful abbey (Condat became so only after the Life was written). Rather, it shows that, in the fifth century, the maintenance of a monastery was not a given and that monks consequently had to struggle, in a process of trial and error, for their subsistence.

In the Life of the Jura Fathers, Romanus enters the Jura forests around 435 as a new Anthony. ${ }^{94}$ The place he chose to settle, "a small plain « enclosed by three mountains (the Avignon, the Bayard, and the Chabot) at the confluence of two rivers (the Bienne and the Tacon), was "suitable and appropriate to his monastic intention «. ${ }^{95}$ It was a "desert", an »inaccessible solitude" that "was many miles distant from any habitation because of the scarcity of dwelling places $" \cdot{ }^{96}$ At the foot of the Bayard, Romanus sheltered under "a dense fir tree whose branches, spread out in a circle, were covered with an abundance of leaves", just beside »a flowing spring [which] poured forth an icy cold stream of water $" .{ }^{97}$ He was so isolated there that he »enjoyed the sight of nothing except wild beasts and, rarely, hunters ${ }^{98}{ }^{98}$ The anonymous author even conjectures about the reasons that supposedly made the site so remote:

91 Vita patrum iurensium 1-2, ed. Martine, 238. For the date, cf. Masai, "Vita patrum iurensium «, 56-57.

92 Scholars have attributed the authorship of the Vita patrum iurensium to Viventiolus, who was ordained as bishop of Lyon in 515. Cf. Moyse, Origines du monachisme, 44; Wood, Prelude to Columbanus, 27-28, n. 118; de Vogüé, Histoire littéraire, vol. 8, 123-126. On the reliability of the Vita patrum iurensium, cf. Martine, Vie.

93 De Vogüé, Histoire littéraire, vol. 8, 41.

94 Vita patrum iurensium 12, ed. Martine, 252: Romanus is an »imitator Antonii«. On the reminiscences of the Life of Anthony in the beginning of the Vita patrum iurensium, cf. the commentaries of Martine, Vie; and of Vivian et al., Life; as well as de Vogüé, Histoire littéraire, vol. 8, 46-52.

95 Vita patrum iurensium 6, ed. Martine, 244: »[...] professioni congruas aptasque [...] in planitiem aliquantulum [...]«. Trans. Vivian et al., Life, 102-103.

96 Vita patrum iurensium 5, ed. Martine, 244 (secretis heremi); 9, ed. Martine, 248 (solitudinem ipsam inviam); 12, ed. Martine, 252 (secreto heremi); 13, ed. Martine, 254 (heremo); 8, ed. Martine, 246: »[...] non parvis spatiis ob raritatem consistentium distabat ab incolis [...] . Trans. Vivian et al., Life, 104.

97 Vita patrum iurensium 7, ed. Martine, 246: »[...] repperit ab orientali parte sub radice saxosi montis, porrectis in orbitam ramis, densissimam abietem, quae patulis diffusa comis [...]. Extra cuius arboris orbem fons inriguus gelidissima fluenta praestabat [...]«. Trans. Vivian et al., Life, 103. Cf. Rothé, Carte archéologique, 631-632.

98 Vita patrum iurensium 12, ed. Martine, 252: "[...] nullo nisi ferarum ac raro venantium frueretur adspectu [...]«. Trans. Vivian et al., Life, 106. 
the abundant cultivation in the distant plain had given no reason to cross a succession of forests in order to come live in the vicinity. Moreover, if someone decided, with audacious daring, to cut across this roadless wilderness toward the territory of the Equestres, in addition to the dense forest and the heaps of fallen trees, he found high and lofty mountain ridges and steep valleys dividing the regions. There stags and broad-horned deer live. Even if the traveler were strong and lightly equipped, he would scarcely be able to cross it in a day, even the longest day of the year. Given the distance and the difficulties of its natural inaccessibility, no one could blaze a trail through this mountain range, to right or to left, from the regions of the Rhine and the raging of the north wind all the way to the farthest wooded regions. ${ }^{99}$

Despite the accuracy with which the Life of the Jura Fathers describes the local geography, ${ }^{100}$ Romanus' establishment appears as highly romanticized. The mountain, the tree and the spring, for example, are clear references to Jerome's Life of Paul, as the author himself emphasized. ${ }^{101}$ Considering the cold weather of the region, as the Life of the Jura Fathers repeatedly remarks, it would have been challenging, if not impossible, for Romanus to shelter under a tree. And indeed, Romanus appears to be living in a hut (tugurium) when his brother Lupicinus comes to find him. ${ }^{102}$ The chapters about Romanus' establishment in the Jura (4-12), therefore, are fundamentally a literary construction. The author goes out of his way to adjust the Jura forests and Romanus to the model of the desert and the founding Fathers of Egyptian monasticism. ${ }^{103}$

But in his explanation on why the Jura forests were supposedly so isolated, the anonymous author abandons the model of Anthony and Paul. Such abandonment does not make the explanation more reliable than the description of Romanus' lifestyle, for the site in which he settled was quite probably at the intersection of two roads (see below). It did not even occur to the author to question the isolation of the site. In fact, he tried to imagine how it would have looked at the time of Romanus for it to be so isolated. But in that imaginative recreation, monastic literature was not at play. The author reverted instead to particularities of the human and natural environments of the Jura (the cultivation of plain and fertile areas in other places, the dense forest, the roughness of the area around Condat, and the distance to other cities).

99 Vita patrum iurensium 8-9, ed. Martine, 246 and 248: "[...] quia abundans procul in campestri cultura minime per successionem silvae illic permiserat quempiam vicinari. Ceterum, si quis solitudinem ipsam inviam contra Aequestris territorii loca ausu temerario secare deliberet, praeter concretionem silvestrem sive congeries arborum caducarum, inter iuga quoque praecelsa cervorum platocerumve praerupta convallia, vix validus expeditusque poterit sub longa solstitii die transcendere. Nam dextra, certe sinistra, serrae ipsius tractum, a limite scilicet Rheni sive flatibus aquilonis usque pagi Nemausatis extimum, nullus omnino ob longitudinem vel difficultatem inaccessibilis naturae poterit penetrare«. Trans. Vivian et al., Life, 104.

100 Martine, Vie, 264, n. 1.

101 For the references, cf. Martine, Vie, 247, n. 2; de Vogüé, Histoire littéraire, vol. 8, 48.

102 Vita patrum iurensium 12, ed. Martine, 252; de Vogüé, Histoire littéraire, vol. 8, 48.

103 Vivian et al., Life, 88; de Vogüé, Histoire littéraire, vol. 8, 51-52.

medieval worlds $•$ No. $9 \cdot 2019 \cdot 82-111$ 
According to the Life of the Jura Fathers, Romanus also imitated Anthony in the practice of manual labor. ${ }^{104}$ Romanus' "small plain « was "an open area that could be cultivated «, and he »brought seeds and a hoe with him $"{ }^{105}$ In this way, »between the times required for frequent prayer and reading ", he cultivated a small plot »to support a modest way of life there by means of the monastic institution of manual labor $« .{ }^{106}$ And similarly to Paul the Hermit, he ate the fruits supplied by »a few wild bushes « ${ }^{107}$

The growing number of disciples, however, led Romanus and his brother Lupicinus, who had joined him, to change residence from their hut to the top of "a small hill« nearby, where the cathedral of Saint-Claude now lies. They hewed the trees and "constructed small dwellings for themselves and prepared others for those who would come in the future ${ }^{108}$ But the number of monks and pilgrims grew so much that the crops became insufficient to feed all: "Suspended as the place was in hills and declivities, between overhanging cliffs and rocky ground, and disturbed by the frequent flooding of the rugged landscape, the cultivation of crops there waned and decreased, not only because of the limited and difficult terrain, but also the mediocre harvests and uncertain yields «. ${ }^{109}$

Because Condat was founded at the top of a hill, the monks transferred Romanus' original crops in the "small plain « to the "gentle slope " of the hill itself. But with the constant growth of mouths to feed, it proved a failure, for the crops on the sloping terrains not only required more labor, but were also quite unproductive and more prone to flooding. The author of the Life of the Jura Fathers gives even more details why the crops failed:

The harsh winter not only covers the place with snow but buries it; so too in the spring and summer and fall either the summer heat, warmed by the nearby rocks, burns everything, or the irresistible rains carry away in torrents not only the tilled and cultivated land, but often the uncultivated and stony earth, too - along with grass, trees, and shrubs. When the rocks are laid bare, the very clods of earth that still remain are carried off from the monks and given over to the waters. ${ }^{110}$

104 I have already dealt with some of the questions that follow in Figuinha, Vida dos Padres do Jura.

105 Vita patrum iurensium 6, ed. Martine, 244: »[...] culturae patulum locum [...]«. Trans. Vivian et al., Life, 103; 10, ed. Martine, 248: »[...] adlatis seminibus vel sarculo [...] «. Trans. Vivian et al., Life, 104.

106 Vita patrum iurensium 10, ed. Martine, 248: "Igitur, adlatis seminibus vel sarculo, coepit illic vir beatissimus inter orandi legendique frequentiam necessitatem victus exigui institutione monachali labore manuum sutentare [...] . Trans. Vivian et al., Life, 104.

107 Vita patrum iurensium 8, ed. Martine, 246: „Erant praeterea paucae silvestres arbusculae, quae [...] pomula ministrabant«. Trans. Vivian et al., Life, 103. Cf. de Vogüé, Histoire littéraire, vol. 8, 48, for the reminiscence of the Life of Paul.

108 Vita patrum iurensium 13, ed. Martine, 254: »[...] in quodam molli colliculo [...] et sibi construxere habitacula et praeparavere venturis«. Trans. Vivian et al., Life, 107.

109 Vita patrum iurensium 22, ed. Martine, 262: "Siquidem cultura loci ipsius pendula collibus vel adclinis inter eminentes scopulos vel acervos, crebro salebrarum labefactata conluvio, non solum in spatiis parva ac difficilis, sed etiam in ipsis frugibus, reditu nutante, torpuerat«. Trans. Vivian et al., Life, 112.

110 Vita patrum iurensium 23, ed. Martine, 262 and 264: "Nam ut hiemali asperitate loca ipsa non solum sunt nivibus obruta, sed sepulta, ita verno aestivoque vel autumnali tempore aut aestas alterno vicinoque saxorum vapore conflagrat, aut intolerabiles imbres non solum eventilatam culturis asportant in torrentibus terram, sed ipsam etiam incultam ac rigidam saepe cum herbis et arboribus ac frutectis, cum gleba quoque ipsa, nudatis quibus insiderat saxis, aufertur monachis, aquis infertur«. Trans. Vivian et al., Life, 112. 
The monks then "cut down and removed the fir trees in the neighboring forests, which were by no means lacking in level and fertile areas", and founded the monastery of Laucone there, close to the current city of Saint-Lupicin. According to the anonymous author, the monks "leveled the fields with the sickle, and the plains with the plow, so that these places, now fit for cultivation, would alleviate the needs of the monks of Condadisco «. ${ }^{111}$ If we believe the author, the foundation of Laucone, certainly intended to allow the expansion of the crops to the new place, brought an abundance of food. He even recounts how the devil, resorting to "the abundance and fruitfulness of the harvest «, »incited the brothers to rise up, not only against the Rule, but almost against the abbot himself « ${ }^{112}$ In the whole Life, indeed, we find indications that Laucone grew to a complex farm. The author mentions its granary and storeroom, which were managed by a steward, its garden, in which vegetables were cultivated, and its fields, which were situated at some distance from the residential building and in which grains and turnips were cultivated. ${ }^{113}$ The rearing of cattle, poultry, and sheep is also referenced. ${ }^{114}$

Not surprisingly, the Jura monasteries have been described as being sections of Romanus' and Lupicinus' family villa, which, due to the villa crisis of the fifth century, was restructured into "smaller productive units ${ }^{115}$ One of the signs of such a restructuring would be the monks' dedication to agriculture and, similar to the Marchiennes and Hamage abbeys (both founded in the seventh century), the employment of slaves or salaried workers. ${ }^{116}$ However, we must be careful not to project on Condat, Laucone, or on any other monastery of the time the social and economic organization of medieval monasteries, for there is no indication concerning the use of slaves or salaried workers in the Life of the Jura Fathers. Actually, it is always the monks who work: Lupicinus, at least sometimes, went ad culturam; ${ }^{117}$ once, all the monks went ad agriculturam to work; ${ }^{118}$ the deacon Sabinianus "was in charge of the mills and tilting hammers on the nearby river below the monastery of Condadisco, which

111 Vita patrum iurensium 24, ed. Martine, 264: "[...] in vicinis exinde silvis quae et planitie et fecunditate minime fallebantur, exsectis excisisque abietibus, aut falce in prata aut vomere in aequora conplanarunt, ut loca oportuna culturis Condatescensium inopiam sublevarent«. Trans. Vivian et al., Life, 112.

112 Vita patrum iurensium 35, ed. Martine, 278: »[...] non solum contra regulam, sed in ipsum paene patrem fecit insurgere fratres. Primitus namque materia huiusce modi exstitit ubertas fecunditasque fructuum [...]«. Trans. Vivian et al., Life, 119.

113 Vita patrum iurensium 68 and 69, ed. Martine, 314 and 316 (spicarium); 75, ed. Martine, 320 (cellariolum); 68, 70, 75, and 172, ed. Martine, 314, 316, 320, and 424 (oeconomus); 73 and 75, ed. Martine, 320 (hortellus); 76, ed. Martine, 322 (hortulus); 64, ed. Martine, 310 (etiamsi [Lupicinus] prolixius egressus est ad culturam); 102, ed. Martine, 346 (fomites and rapae).

114 Vita patrum iurensium 66, ed. Martine, 312: "Nam cum nullus in Condatescensi praesertim coenobio hodie usque in Christi nomine de animali quicquam, exceptis lactibus, aut de alitibus, praeter ovis, infirmans dumtaxat, audeat degustare [...]«; 74, ed. Martine, 320: »[...] expansis in terra vervecum pellibus [...]«; 173, ed. Martine, 424: »[...] lanasque netas etiam suendi consuendique [...]«. Cf. Rothé, Carte archéologique, 167. For an overview of agrarian production and its social organization in Late Antiquity, cf. Wickham, Framing, 259-302 and 383-588.

115 Alciati, Sistema agricolo familiare, who refers to Condat.

116 Alciati, Sistema agricolo familiare, 135-139. Alciati also considers indications of the restructuring of Romanus' and Lupicinus' villa the fact that Romanus settled in the Jura forests close to his villa (Vita patrum iurensium 5, ed. Martine, 244) and the practice of artisanal labor. In my opinion, however, the proximity of Romanus' settlement to his villa and the dedication to artisanal labor do not per se indicate that Condat was the result of the fragmentation of his property. We would need more evidence concerning specifically the Jura monasteries to state that.

117 Vita patrum iurensium 64, ed. Martine, 310.

118 Vita patrum iurensium 73, ed. Martine, 318.

medieval worlds • No. 9 • 2019 • 82-111 
served the brothers", and he had a "little hut « there; ${ }^{.19}$ when Sabinianus decided to undertake a larger task, he called for the help of monks; ${ }^{120}$ the monk Dativus, who »by divine help [...] was also adorned with great qualities and gifts for every kind of work «, took his utensils with him when he left the monastery; ${ }^{121}$ and monks had hoes or axes in their personal cells before such cells caught fire and were replaced by a common dormitory. ${ }^{122}$ In fact, the eighth canon of the Council of Épaone, gathered in 517, indicates that, at the time, some monks of the Burgundian kingdom still refused to use slaves in their fields. ${ }^{123}$

The Jura monks also constructed mills and tilting hammers (pisae) on the Tacon to maximize their labor. ${ }^{124}$ As we have just seen, a single monk, Sabinianus, was in charge of the operation of this machinery and therefore had his cell there. Unfortunately, the author does not tell us when this machinery was originally built. But since he praises Sabinianus in the Life of Romanus and states that Sabinianus was a disciple of Stephen, »the first person to hold this ministry «, ${ }^{125}$ we can assume that it occurred soon after the monks transferred the crops to the sloping terrain around Condat. When they expanded the crops to Laucone, they had to bring the grain from there to Condat, grind it, and take some back to Laucone. We should also note that this machinery was perfected through the years. The anonymous author recounts the works coordinated by Sabinianus to "raise the channel of the river by which water was brought to the mill ${ }^{126}$ His intention was certainly to increase the speed of the grinding process.

But we cannot accept all too quickly the author's portrait and suppose that Condat and Laucone became economically autonomous. For, despite the practice of agriculture and animal breeding and the use of technology, the monks actually could not produce all the food they and their guests consumed. In his Life of the Fathers, Gregory of Tours recounts an episode that is absent in the Life of the Jura Fathers. The account is highly hagiographic, but it most probably derives from a historical episode. Between 463 and 469, Lupicinus came to Geneva to ask the Burgundian king Chilperic for a contribution to the Jura monasteries. ${ }^{127}$

119 Vita patrum iurensium 52, ed. Martine, 296: »[...] in vicino flumine sub ipso Condatescensi coenobio molinas pisasque fraternis usibus gubernabat [...]«. Trans. Vivian et al., Life, 127, slightly adapted; 53, ed. Martine, 298.

120 Vita patrum iurensium 57, ed. Martine, 300 and 302

121 Vita patrum iurensium 87, ed. Martine, 332: »[...] gratiarum dotibus in omni artificio divinitus adornatus«. Trans. Vivian et al., Life, 142; 88, ed. Martine, 332.

122 Vita patrum iurensium 163 and 170, ed. Martine, 414 and 422. That is why I am of the opinion that the two fratres who planned to leave the monastery taking a hoe and an axe with them (Vita patrum iurensium 79, ed. Martine, 324 and 326) were monks, not »operai salariati« or "schiavi«, as Alciati supposes.

123 The possession of slaves seems inconsistent with the words attributed by Gregory of Tours to Lupicinus in his meeting with the Burgundian king Chilperic (see below).

124 Vita patrum iurensium 52, ed. Martine, 296.

125 Vita patrum iurensium 52, ed. Martine, 296: "[...] ministerii huius principem Stephanum [...]«. Trans. Vivian et al., Life, 127.

126 Vita patrum iurensium 57, ed. Martine, 300: »[...] alveum torrentis ipsius quo molinaris advehebatur aqua [...]«. Trans. Vivian et al., Life, 129.

127 It is usually assumed that this episode occurred at the same time Lupicinus came to Chilperic's court to plead "[...] pro adflictione pauperum, quos persona quaedam, honore dignitatis aulicae tumens, vi pervasionis inlicitae servitutis iugo subdiderat [...] (Vita patrum iurensium 92, ed. Martine, 336, see below). However, Vita patrum iurensium 63, ed. Martine, 310, attests that Lupicinus came to the court more than once to act as an intercessor: "Calciamento namque tum tantummodo usus est, cum pro aliquibus forsitan ad comitatum intercessurus egressus est «. In any case, Lupicinus' request for a contribution to the Jura monasteries quite probably dates from the same timespan as his pleading in favour of the enslaved poor, i.e. 463-469. On this timespan, cf. Favrod, Histoire politique, 102, n. 120. 
As Lupicinus told him: "II am the father of the Lord's sheep. The Lord nourishes them with spiritual food, under the yoke of discipline, but they now lack bodily food. This is why we implore Your Potency that you might give us something for our food and clothing « ". ${ }^{128}$ Chilperic offered Lupicinus "fields and vineyards «, but he refused. Lupicinus requested instead: ")We will not accept fields and vines; but, if it pleases Your Potency, give us some of the fruits that they produce. It does not suit monks to live by worldly riches [...] « ${ }^{129}$ Chilperic then donated him "an order to receive each year 300 modii of wheat and the same measure of wine, and 100 gold solidi for clothing for the brothers". According to Gregory, "Even now they receive all this, it is said, from the estates of the fisc «. ${ }^{130}$

The Life of the Jura Fathers recounts that »the enormous community of monks and the multitude of lay people who had come to the monastery « was menaced only once by an »imminent scarcity and the danger of famine«. The steward told Lupicinus that there was "nothing more than a fifteen-day supply of food for the three months that remained until the new harvest promised relief . ${ }^{131}$ Lupicinus prayed into the granary and miraculously multiplied the grain, thus saving the monks and pilgrims from starvation. This episode, however, may well be related to Gregory's account, for the author of the Life of the Jura Fathers may have transformed Lupicinus' success at the court of Chilperic into a miraculous multiplication of grain.

The Life of the Jura Fathers and the account De Lupicino atque Romano abbatibus in the Life of the Fathers have analogies that have prompted scholars to consider that they derive from a short and more ancient Life of Romanus and Lupicinus. ${ }^{132}$ Gregory may have learned about Lupicinus' request of a contribution to Chilperic through this Life, but the author of the Life of the Jura Fathers may also have learned about it through oral reports and accounting records as a member of Condat. If in the end he excluded the episode from his narrative, it is because it did not fit his purposes. The composition of the Life was prompted by John and Armentarius, two members of the monastery attached to the shrine of Saint-Maurice in Agaune, soon after they read »the institutes regarding the rules and regulations " the same author, at the request of the abbot Marinus of Lérins, had sent to their monastery. ${ }^{133}$ The Life of the Jura Fathers was thus intended as a complement to such

128 Gregory, Liber vitae patrum 5, ed. Krusch, 217: "'Pater sum`, inquid, >dominicarum ovium, quas cum Dominus spiritalibus cibis iugi administratione reficiat, corporalia eis interdum alimenta deficiunt. Ideo petimus potentiae vestrae, ut ad victus vestitusque necessaria aliquid tribuatis«". Trans. James, Life of the Fathers, 9.

129 Gregory, Liber vitae patrum 5, ed. Krusch, 217: »Rex vero haec audiens, ait: >Accipite agros vineasque [...] . Qui respondit: >Agros et vineas non accipiemus, sed, si placet potestati vestrae, aliquid de fructibus deligate. Quia non decet, monachos facultatibus mundanis extolli [...] «. Trans. James, Life of the Fathers, 9-10.

130 Gregory, Liber vitae patrum 5, ed. Krusch, 217: »At rex [...] dedit eis praeceptionem, ut annis singulis trecentos modios tritici eiusdemque mensurae numero vinum accipiant et centum aureos ad conparandum fratrum indumenta. Quod usque nunc a fisci ditionibus capere referuntur«. Trans. James, Life of the Fathers, 10.

131 Vita patrum iurensium 68, ed. Martine, 314: »[...] cum enormis congregatio atque expetentum saecularium multitudo, iam iamque inminente penuria, famis periculo conturbaret oeconomum, ac praeter dierum quindecim victum trimenstre tempus, donec seges nova succurreret, penitus nihil haberet [...]«. Trans. Vivian et al., Life, 135.

132 Martine, Vie, 72-73, n. 2.

133 Vita patrum iurensium 1-2, ed. Martine, 238; 179, ed. Martine, 432: "[...] instituta quae de informatione monasterii vestri [...] «. Trans. Vivian et al., Life, 184. As Masai, »Vita patrum iurensium«, has pointed out, »le coenobium auquel la Vie des Pères du Jura fut destinée n'était pas l'abbaye de Sigismond. Celle-ci n'existait pas encore à l'époque où la >Vita` fut écrite!« (p. 56). The author also notes that »les correspondants du moine de Condat ne sont pas, comme on l'a cru à tort, des religieux expérimentés, mais des novices au contraire, en quête d’instructions et de modèles de vie pour s'organiser en coenobium « (pp. 57-58). 
»institutes", to show John and Armentarius, through the deeds of the three abbots, how monasticism should be practiced. Hence the title, Life and Rule of the Holy Fathers Romanus, Lupicinus, and Eugendus, Abbots of the Jura Monasteries, attributed to the text. ${ }^{134}$ In such a Life and Rule, the anonymous author praised the model of Basil, Lérins, Pachomius, and Cassian, ${ }^{135}$ and therefore situated the Jura monasteries in a desert and, most importantly, presented them as economically autonomous, as if the monks could support themselves only through their work. If the author had included Lupicinus' request to Chilperic in his narrative, he would have compromised the image of the Jura Fathers he was aiming to project.

Despite the omission of Lupicinus' appeal to Chilperic, the author of the Life of the Jura Fathers may have subtly alluded to the fact that the Jura monks could not produce all the food they consumed in his meticulous explanation why the crops failed in Condat. From chapter 22 to chapter 23 , tenses change from the past perfect to the present. The reason for that, I argue, is that in chapter 23 the author is resorting to his own experience. He probably supposed that, other than the inclination of the terrains in Condat, Romanus and Lupicinus had faced the same difficulties his contemporaries still faced more than seventy years later. If this is indeed the case, it corroborates the fact that the monks were unable in the long term to harvest abundant crops in the areas they deforested. ${ }^{136}$

What is even more important to note is that the author of the Life of the Jura Fathers is so meticulous in chapters $22-23$ because he is explaining to his most immediate readers, John and Armentarius, why the crops failed at the time of Romanus and in his own time. In this way, he is implicitly justifying to John and Armentarius, who certainly knew the Jura monasteries very well, why the latter had to be maintained by the Burgundian kings. These chapters, indeed, summarize a tension that is perceptible in the whole text between the ideal monastic life, as it is advertised in more ancient hagiographic and monastic texts, and the real monastic life, constrained by the local natural environment. In the Life of Romanus, the Jura forests change from the perfect place for a monastic life at the beginning to a hindering to the monastic life after the foundation of Condat. The Jura monks had been very much influenced by Cassian, who argued that monks should sustain themselves only through the practice of manual labor. ${ }^{137}$ But in the Jura forests, even though they worked hard, the monks could not live only on what they produced. They could not be like the monks Cassian had presented. And the fault for that was to be attributed to the local natural environment, which was not favorable to agriculture. That is why the author says at the end of the Life of Eugendus that, despite reading "daily" the "institutions" of Basil, Lérins, Pachomius, and Cassian, the Jura monks "strive to follow those of Condadisco « ${ }^{138}$ The institutions of Condat, he continues, had been formulated pro qualitate loci et instantia laboris, "according to the features of the place and the requirements of labor «. The Jura monks soon realized, therefore, that, despite all their effort, they could not live like the monks they knew through their books.

134 Vita vel regula sanctorum patrum Romani Lupicini et Eugendi monasteriorum iurensium abbatum, ed. Martine, 236. On this aspect of the text, cf. Wood, Prelude to Columbanus, 4; Diem, Who is allowed, 57.

135 Vita patrum iurensium 174, ed. Martine, 426.

136 Rothé, Carte archéologique, 651: the soil of Saint-Lupicin has been qualified as "'peu fertile««.

137 On Cassian's thoughts on manual labor, cf. Goodrich, Contextualizing Cassian, 198-200.

138 Vita patrum iurensium 174, ed. Martine, 426 and 428. Trans. Vivian et al., Life, 182.

medieval worlds • No. 9 • 2019 • 82-111 
The author omits not only the Burgundian kings' contribution to the Jura monasteries, but also pilgrims' donations to the monks. In the Life of Lupicinus, he attests that monks "frequently accomplished gifts of healing and other wonders " and went away "without receiving any kind of monetary gift in return «. ${ }^{139}$ But he is clearly being rhetorical, for he is contrasting his own time with the mythical one of the founding Fathers. Lupicinus and Eugendus were closely connected with powerful people who may well have made donations to them: Domnulus, a poet and quaestor sacri palatii during the reign of Majorian (457-461), was a frequent guest of the Jura monasteries; Agrippinus, after his tenure as comes and magister militum in Gaul (451-456), was freed from the charge of high treason through the miraculous intercession of Lupicinus; and Syagria, member of a powerful family of Lyon, was cured of a "grave disease « through a letter of Eugendus. ${ }^{140} \mathrm{In}$ fact, the author noted »that the greatest and most powerful people of the time frequently asked to be protected and blessed by his [Eugendus'] letters « ${ }^{141}$ It is certainly not by chance that he presents Syagria as a »formerly mother of a family, and now through her almsgiving mother of churches and monasteries «. ${ }^{142}$ He probably intended to praise her for her contributions to the Jura monasteries without saying directly that she had made any contributions.

A last point concerning the account of Romanus' establishment in the Jura forests is that Condat was not isolated. ${ }^{143}$ It was quite likely at the intersection of an East-West road that connected Geneva to Izernore (Romanus', Lupicinus', and Eugendus' hometown) ${ }^{144}$ through the Bienne valley and a North-South road. ${ }^{145}$ The author himself mentions the road to Geneva. ${ }^{146}$ It is also possible that two roads, one that connected Geneva to Lons-le-Saunier through Condat and the other that connected Fort-du-Plasne to Izernore, passed close to Laucone. ${ }^{147}$ Condat and Laucone, moreover, were close to inhabited sites, as archaeological discoveries a few miles away from Saint-Claude suggest. ${ }^{148}$ The author's allusion to "local inhabitants" (indigenis) and the hunters Romanus saw at the beginning of his retreat in the Jura (if it is not purely a romantic idealization) are also indications of it. ${ }^{149}$ Condat's own

139 Vita patrum iurensium 114, ed. Martine, 358: "[...] saepe per Domini servos [...] sanitatum et mirabilium dona perfecta sunt $[. .$.$] absque venalitate gratiae festinabant [...] «. Trans. Vivian et al., Life, 154$.

140 Domnulus: Sidonius Apollinaris, Epistula 4.25.5, ed. Loyen, 170; Agrippinus: Vita patrum iurensium 96-110, ed. Martine, 342-354; Syagria: Vita patrum iurensium 145-146, ed. Martine, 394 and 396. On them, cf. Pietri and Heijmans, Prosopographie chrétienne.

141 Vita patrum iurensium 139, ed. Martine, 388: »[...] summae saeculi potestates sospitari se crebro ac benedici eius litteris exorarent [...]«. Trans. Vivian et al., Life, 166.

142 Vita patrum iurensium 145, ed. Martine, 394: "Materfamilias quondam Syagria, nunc quoque ecclesiarum monasteriorumque per eleemosynam mater [...]«. Trans. Vivian et al., Life, 169.

143 As has been well known since specially Mordefroid, Quel désert.

144 Vita patrum iurensium 120, ed. Martine, 366.

145 On these and the other roads in the Jura, cf. Rothé, Carte archéologique, 82-88 and 168. Scholars have been aware of this aspect of Condat since Wood, Prelude to Columbanus, 5 .

146 Vita patrum iurensium 153, ed. Martine, 402: »[...] semitam qua Genuam usque transcenditur [...]«.

147 Rothé, Carte archéologique, 651.

148 Mordefroid, Quel désert, 7-9; Bully, Archéologie.

149 Vita patrum iurensium 145 and 12, ed. Martine, 394 and 252.

medieval worlds • No. 9 • 2019 • 82-111 
site had already been inhabited. In a campaign conducted in the cathedral of SaintClaude, archeologists brought to light objects and remains of a prehistoric occupation and of a second-century building. ${ }^{150}$ It may well be, as some scholars have considered, that Romanus chose the site in order to Christianize the local territory. ${ }^{151}$

The connection of Condat and Laucone with Christian and commercial centers appears many times in the Life of the Jura Fathers. Romanus and Lupicinus were frequently on the road. Romanus even had a trip companion and miracles are attributed to Romanus while he was in Poncin and Geneva. ${ }^{152}$ Lupicinus sometimes went "to the [Burgundian] court in order to intercede on behalf of this or that person ${ }^{153}$ Probably in 467 , he came to Chilperic "moved by the plight of some poor persons whom a certain man, puffed up by the prestige of being at court, had through unlawful coercion violently subjected to the yoke of servitude ${ }^{154}$ At the time of Lupicinus, monks were "sent out of the monastery by the abbot for some reason or other " and two monks came to Rome and stayed out for around two years. ${ }^{155}$ During Eugendus' abbacy, monks continued to travel to the north of Condat despite fearing "the terrible incursions of the Alemanni in their very neighborhood «. ${ }^{156}$

The author contrasts Romanus and Lupicinus, who "often left the monastery, going here and there on acts of mercy «, to Eugendus, who, "after he entered the monastery, never took a step outside «. ${ }^{157}$ As I have already mentioned, however, Eugendus was constantly reached by mail from "the greatest and most powerful people of the time « requesting "to be protected and blessed by his letters". These people either sent letters or came personally to the Jura to get "the special favor or intercessions of the friend of Christ $"{ }_{.}^{158}$ In the Life, indeed, Condat and Laucone seem always crowded by clerical and secular visitors. Since the beginning, as the anonymous author asserts, Romanus' and Lupicinus' "renown [...] persuaded throngs of believers " to join them in the monastic life. "Some came there" - he continues - "to see the miracles of this institution and to take home with them exemplary and harmonious gifts",

150 Mordefroid, Quel désert, 6-7.

151 Vivian et al., Life, 88; Bully and Mordefroid, De Saint Désiré, 178.

152 Vita patrum iurensium 44, ed. Martine, 286 (trip companion); 43, ed. Martine, 286 (Poncin); 44-50, ed. Martine, 286-294 (Geneva).

153 Vita patrum iurensium 63, ed. Martine, 310: »[...] pro aliquibus forsitan ad comitatum intercessurus egressus est «. Trans. Vivian et al., Life, 134.

154 Vita patrum iurensium 92, ed. Martine, 336: „Quadam namque vice, dum pro adflictione pauperum, quos persona quaedam, honore dignitatis aulicae tumens, vi pervasionis inlicitae servitutis iugo subdiderat [...]«. Trans. Vivian et al., Life, 144. For the date, cf. Favrod, Histoire politique, 102: »entre 463 et 469, très probablement vers $467 \lll$.

155 Vita patrum iurensium 113, ed. Martine, 358: »[...] frater ab abbate foras ob causam aliquam destinatus [...] «. Trans. Vivian et al., Life, 153-154; 155, ed. Martine, 404 (trip to Rome).

156 Vita patrum iurensium 157, ed. Martine, 406: »[...] diros metuunt ac vicinos Alamannorum incursus [...]«. Trans. Vivian et al., Life, 173. As Martine, Vie, 407, n. 3, has pointed out, these incursions likely occurred at the beginning of Eugendus' abbacy (from 472-475 to 512-515), before the Burgundians expelled the Alemanni out of Sequania in the second half of the 470 s or in the early 480 s. On the dates of Eugendus' abbacy, cf. Pietri and Heijmans, Prosopographie chrétienne, vol. 1, 679-683.

157 Vita patrum iurensium 126, ed. Martine, 374: "Illis dumtaxat huc illucque necessitate misericordiae e monasterio saepe progressis, iste vero [...] nusquam exinde post ingressum extulit pedem«. Trans. Vivian et al., Life, $160-161$.

158 Vita patrum iurensium 139, ed. Martine, 388: »[...] Christi amici gratiam sive suffragia [...] «. Trans. Vivian et al., Life, 166. Cf. above n. 141. On the Jura Fathers' intercessory activities, cf. Diem, Who is allowed, 61-62. 
while »Others brought people tormented by demons and by other spirits of the Devil, along with the insane and paralyzed, so that through the prayer of the saints and their own faith these might be healed «. ${ }^{159}$ At the time of Eugendus, the ill "seemed almost more numerous than the companies of monks «. ${ }^{160}$

The Jura monks depended on the same roads through which pilgrims reached Condat and Laucone to obtain what they needed, such as honey, olive oil, salt, and wine. ${ }^{161}$ In the Life of Eugendus, the author states that the monks used to get salt in Salins, around forty miles north of Condat. ${ }^{162}$ However, they had other, more distant, options if they needed. On one occasion, some monks went "as far away as the shores of the Mediterranean« in order to avoid "the terrible incursions of the Alemanni ${ }^{163}{ }^{163}$ The products the Burgundian kings annually donated to the Jura monks also reached the monasteries through the roads that connected them with the whole kingdom.

\section{Conclusion}

Although set in very different places, the three cases investigated here display remarkable consistencies regarding the way their members conceived and interacted with the human and natural environments:

1. Relying on both Christian and classical Roman literary traditions, monastic authors presented their or their heroes' monasteries and the local human and natural environments as a "desert", an isolated place. Authors intended to associate themselves or their heroes with the Fathers of Egyptian monasticism and therefore did not hesitate to distort the human and natural environments to achieve their purpose. In truth, there are some particularities. The elements Eucherius used to characterize the fertility of the monastic desert, in general, and of Lérins, in particular, had a Biblical meaning for him, while the anonymous author of the Life of the Jura Fathers resorted to characteristics of the Jura geography and topography to explain the supposed isolation of Romanus' original settlement.

2. Despite the authors' insistence on the monastic desert, the monasteries they describe were not isolated. On the contrary. They were close to inhabited centers and could be easily reached via land and maritime routes.

159 Vita patrum iurensium 14-15, ed. Martine, 254 and 256: »[...] fama [...] credentium turbas persuaderet [...]. Nonnulli institutionis huius visuri miracula atque exempli dona convenientia domi reportaturi conveniunt. Alii etiam vexatos daemoniis ceterisque diaboli larvis oratione sanctorum cum propria fide curandos, et mente inpotes et corpore nexos, adducunt«. Trans. Vivian et al., Life, 107-108. Cf. Wood, Prelude to Columbanus, 5.

160 Vita patrum iurensium 147, ed. Martine, 396: »[...] paene catervis videretur numerosior monachorum«. Trans. Vivian et al., Life, 169.

161 Vita patrum iurensium 116, ed. Martine, 360 (mel); 38, 66, 75, and 170 (to light lamps), ed. Martine, 282, 312, 320, and 422 (oleum); 38 and 157, ed. Martine, 282 and 408 (sal); 66 and 75, ed. Martine, 312 and 320 (vinum). We should not forget that wine was also used at the celebration of the Eucharist.

162 Vita patrum iurensium 157, ed. Martine, 408; Martine, Vie, 409, n. 2.

163 Vita patrum iurensium 157, ed. Martine, 406 and 408: "[...] diros metuunt ac vicinos Alamannorum incursus [...] e limite Tyrreni maris [...] coctile decernunt petere sal«. Trans. Vivian et al., Life, 173. For the date of this instance, cf. n. 156 above. 
3. These monasteries, indeed, could not be isolated, for they depended on the human and natural environments for their subsistence. Their members had to buy the products they could not produce or get in nearby forests, such as food, papyrus, and parchment. It is perhaps important to stress that, even when monks practiced agriculture on large scale, as in the Jura, we cannot assume, as a simple consequence, that they were able to produce all the food they consumed. Part of the money necessary for their subsistence was donated by the devotees and ill people who constantly came to meet them.

Despite these similarities, the monks and monasteries considered in this analysis show that they interfered in very particular ways in the human and natural environments. At Marmoutier, Martin's disciples were not meant to practice manual labor or do any lucrative activities, so that they could dedicate themselves to continuous prayer. There is also no indication that they practiced agriculture or that the monastery owned land properties. Because of that, they quite likely bought most of the food they consumed from local peasants, who were also hired to bring wood from the nearby forest. In the Jura, on the contrary, the monks practiced manual labor with the intention of supporting themselves: they deforested and cultivated large areas, reared cattle, poultry, and sheep, and constructed a mill and tilting hammers to grind grains. In all that, they were trying to follow the precepts of John Cassian.

But because of the difficulties of cultivating the land in the Jura forests, they failed to sustain themselves only through the labor of their hands. They also depended on the contributions of the Burgundian kings and on the donations of pilgrims. At Lérins, though monks were also influenced by Egyptian monasticism and required to work with their hands, it is not certain if they dedicated themselves to agriculture. If they did, the extension of the deforested and cultivated terrain was limited to a small part of the island.

The way monks conceived and practiced monasticism in late antique Gaul was very different from one to the other. ${ }^{164}$ It comes then as no surprise that different monastic practices and conceptions of how monks were to support themselves led to different interactions with the human and natural environments. Unfortunately, we cannot measure their impact on the local economy and the circulation of products, on the circulation of people, and on deforestation and the consumption of natural resources. But, considering the differences in their interactions with their human and natural environments, we can assume quite confidently that their impact on it was particular to each one of them.

\section{Acknowledgements}

This work was supported by Coordenação de Aperfeiçoamento de Pessoal de Nível Superior (CAPES).

164 Cf. especially the works of Diem, Monastisches Experiment; id., Inventing the Holy Rule; id., Who is allowed; id., Gregory's chess board; id., Columbanian monastic rules. 


\section{References}

Abbreviations

CCSL = Corpus Christianorum Series Latina

LCL $=$ Loeb classical library

MGH SRM = Monumenta Germaniae Historica, Scriptores Rerum Merovingicarum

TTH $=$ Translated texts for historians

SC = Sources Chrétiennes

Alciati, Roberto, Un sistema agricolo familiare ovvero ciò che è chiamato il monachesimo del Giura, in: Valerio Neri and Beatrice Girotti (eds.), La famiglia tardoantica: Società, diritto, religione, Quaderni di Erga-Logoi 5 (Milan, 2016) 129-144.

Bord, Lucien-Jean, Aux origines du monachisme en Gaule: Les communautés martiniennes du IVe siècle", Annales de Bretagne et des Pays de l'Ouest 119 (2012) 13-24.

Brown, Peter, Through the Eye of a Needle: Wealth, the Fall of Rome, and the Making of Christianity in the West, 350-550 AD (Princeton, 2012).

Bully, Sébastien, Archéologie des monastères du premier millénaire dans le Centre-Est de la France: Conditions d'implantation et de diffusion, topographie historique et organisation, Bulletin du Centre d'Études Médiévales d'Auxerre 13 (2009) 257-290.

Bully, Sébastien and Jean-Luc Mordefroid, De Saint Désiré à Saint Claude (v. 400-v. 700): Les premières communautés chrétiennes du Jura - Notes, documents et perspectives de recherche, in: Marie-Pierre Rothé, Carte archéologique de la Gaule, vol. 39: Le Jura (Paris, 2001) 176-183.

Caner, Daniel, Wandering, Begging Monks: Spiritual Authority and the Promotion of Monasticism in Late Antiquity, The Transformation of the Classical Heritage 33 (Berkeley, 2002).

Chadwick, Owen, Euladius of Arles, Journal of Theological Studies 46 (1945) 200-205.

Codou, Yann, Aux origines du monachisme en Gaule (Ve-XIe s.): Les fouilles de l'église du Saint-Saveur, Lérins, île Saint-Honorat, Alpes-Maritimes, Hortus Artium Medievalium 19 (2013) 63-71.

Codou, Yann, Aux origines du monachisme: Le dossier de Saint-Honorat de Lérins, in: Michèle Gaillard (ed.), L'empreinte chrétienne en Gaule du IVe au IXe siècle (Turnhout, 2014) 291-310.

Codou, Yann, Îles de Lérins. Île Saint-Honorat, les chapelles du Saint-Sauveur et de la Trinité, in: Monuments de Nice et des Alpes-Maritimes, Congrès archéologique de France (Paris, 2012) 77-84.

Codou, Yann, Les îles de Lérins, in: Laurence Lautier and Marie-Pierre Rothé, Carte archéologique de la Gaule, vol. 06: Les Alpes-Maritimes (Paris, 2010) 269-283.

Courcelle, Pierre, Nouveaux aspects de la culture lérinienne, Revue des études latines 46 (1968) 379-409.

Diem, Albrecht, Columbanian monastic rules: Dissent and experiment, in: Roy Flechner and Sven Meeder (eds.), The Irish in Early Medieval Europe: Identity, Culture and Religion (London, 2016) 68-85.

Diem, Albrecht, Das monastische Experiment: Die Rolle der Keuschheit bei der Entstehung des westlichen Klosterwesens, Vita Regularis 24 (Münster, 2005). 
Diem, Albrecht, Gregory's chess board: Monastic conflict and competition in Early Medieval Gaul, in: Philippe Depreux, François Bougard and Régine Le Jan (eds.), Compétition et sacré au haut Moyen Âge: Entre médiation et exclusion, Haut Moyen Âge 21 (Turnhout, 2015) 165-191.

Diem, Albrecht, Inventing the Holy Rule: Some observations on the history of monastic normative observance in the Early Medieval West, in: Hendrik Dey and Elizabeth Fentress (eds.), Western Monasticism ante litteram: The Spaces of Monastic Observance in Late Antiquity and the Early Middle Ages, Disciplina Monastica 8 (Turnhout, 2011) 53-84.

Diem, Albrecht, Who is allowed to pray for the king? Saint-Maurice d'Agaune and the creation of a Burgundian identity, in: Walter Pohl and Gerda Heydemann (eds.), Post-Roman Transitions: Christian and Barbarian Identities in the Early Medieval West, Cultural Encounters in Late Antiquity and the Middle Ages, Identities in the Latin West 14 (Turnhout, 2013) 47-88.

Dulaey, Martine, La bibliothèque du monastère de Lérins dans les premières décennies du Ve siècle, Augustinianum 46 (2006) 187-230.

Eucherius, De laude eremi, ed. Salvatore Pricoco, Eucherio. Elogio dell'eremo, Biblioteca Patristica (Bologna, 2014).

Eusebius Gallicanus, Collectio homiliarum, ed. François Glorie, CCSL 101 (Turnhout, 1970).

Favrod, Justin, Histoire politique du royaume burgonde (443-534), Bibliothèque Historique Vaudoise 113 (Lausanne, 1997).

Figuinha, Matheus Coutinho, A data da Regra dos quatro Padres e o início do monastério de Lérins, Romanitas - Revista de Estudos Grecolatinos 5 (2015) 168-185.

Figuinha, Matheus Coutinho, A Vida dos Padres do Jura e a subsistência dos monges de Condat, História (São Paulo) 34 (2015) 243-262.

Figuinha, Matheus Coutinho, O monasticismo de Martinho de Tours e as aristocracias na Gália do século IV, Revista Brasileira de História 36 (2016) 13-33.

Figuinha, Matheus Coutinho, The economy of the monastery of Lérins (c. 400-c. 460), in: Giovanni Alberto Cecconi, Rita Lizzi Testa and Arnaldo Marcone (eds.), The Past as Present. Essays of Roman History in Honor of Guido Clemente, Studi e testi tardoantichi. Profane and Christian Culture in Late Antiquity 17 (Turnhout, forthcoming).

Figuinha, Matheus Coutinho, The subsistence of Martin of Tours' Marmoutier, in: Bernard Sawicki (ed.), Monasticism and Economy: Rediscovering an Approach to Work and Poverty (Rome, forthcoming).

Fontaine, Jacques, Sulpice Sévère. Vie de Saint Martin, SC 133-135, 3 vols (Paris, 1967-1969).

Fontaine, Jacques and Nicole Dupré, Sulpice Sévère. Gallus: Dialogues sur les "vertus" de Saint Martin, SC 510 (Paris, 2006).

Gillot, Isabelle and Yann Codou, Un témoin de l'environnement de l'île Saint-Honorat de Lérins (Alpes-Maritimes): Le combustible utilisé dans la chapelle Saint-Sauveur durant l'Antiquité tardive et le haut Moyen Âge, Bulletin Archéologique de Provence 38 (2017) 95104.

Gioanni, Stéphane, La culture profane et la littérature monastique en Occident: L'exemple des ascètes provençaux (Ve-VIe siècles), in: Éric Rebillard and Claire Sotinel (eds.), Les frontières du profane dans l'Antiquité tardive, Collection de l'École française de Rome 428 (Rome, 2009) 177-195.

Goodrich, Richard J., Contextualizing Cassian: Aristocrats, Asceticism, and Reformation in Fifth-Century Gaul (Oxford, 2007). 
Gribomont, Jean, L'influence du monachisme oriental sur Sulpice Sévère, in: Élie Griffe (ed.) Saint Martin et son temps. Mémorial du XVIe centenaire des débuts du monachisme en Gaule, 361-1961, Studia Anselmiana 46 (Rome, 1961) 135-149.

Gregory, Liber vitae patrum, ed. Bruno Krusch, MGH, SRM 2 (Hanover, 1885) 211-294; English trans. Edward James, Gregory of Tours: Life of the Fathers, TTH 1 (second edition), (Liverpool, 1991).

Heijmans, Marc and Luce Pietri, Le »lobby « lérinien: Le rayonnement du monastère insulaire du Ve siècle au début du VIIe siècle, in: Yann Codou and Michel Lauwers (eds.), Lérins, une île sainte de l'Antiquité au Moyen Âge, Collection d'Études Médiévales de Nice 9 (Turnhout, 2009) 35-61.

Hilary, Sermo de vita sancti Honorati, ed. Marie-Denise Valentin, Hilaire d'Arles. Vie de Saint Honorat, SC 235 (Paris, 1977).

Honoratus of Marseille, Vita sancti Hilarii episcopi Arelatensis, ed. Paul-André Jacob, Honorat de Marseille. La Vie d'Hilaire d'Arles, SC 404 (Paris, 1995).

Horden, Peregrine and Nicholas Purcell, The Corrupting Sea: A Study of Mediterranean History (Oxford, 2000).

Institutio sanctorum episcoporum in causa insulae Lerinensis, ed. Charles Munier, Concilia Galliae, a. 314-a. 506, CCSL 148 (Turnhout, 1963) 133-134.

Itinerarium provinciarum Antonini Augusti, ed. Gustav Parthey and Moritz Pinder, Itinerarium Antonini Augusti et Hierosolymitanum (Berlin, 1848) 1-234.

John Cassian, Conlationes, ed. Eugène Pichery, Jean Cassien. Conférences VIII-XVII, SC 54 (Paris, 1958).

Kasper, Clemens M., Theologie und Askese: Die Spiritualität des Inselmönchtums von Lérins im 5. Jahrhundert, Beiträge zur Geschichte des alten Mönchtums und des Benediktinertums 40 (Münster, 1991).

Labrousse, Mireille, Les origines du monastère (Ve-VIIe siècle), in: Mireille Labrousse (ed.), Histoire de l'abbaye de Lérins, Cahiers Cisterciens: Des Lieux et des Temps 9 (Bégrolles-enMauges, 2005) 21-124.

Lenkaityté, Manté, Eucher interprète de la Bible dans l'»Éloge du désert«, in: Yann Codou and Michel Lauwers (eds.), Lérins, une île sainte de l'Antiquité au Moyen Âge, Collection d’Études Médiévales de Nice 9 (Turnhout, 2009) 83-104.

Leyser, Conrad, »This Sainted Isle«: Panegyric, Nostalgia, and the Invention of Lerinian Monasticism, in: William E. Klingshirn and Mark Vessey (eds.), The Limits of Ancient Christianity: Essays on Late Antique Thought and Culture in Honor of R. A. Markus (Ann Arbor, 1999) 188-206.

Lorans, Élisabeth, Aux origines du monastère de Marmoutier: Le témoignage de l'archéologie, Annales de Bretagne et des Pays de l'Ouest 119 (2012) 177-203.

Lorans, Élisabeth, Marmoutier (Tours), a late Roman and early medieval monastery in the Loire Valley (4th-11th centuries), Anglo-Saxon Studies in Archaeology and History 20 (2017) 55-66.

Lorans, Élisabeth and Thomas Creissen (eds.), Le site de l'abbaye de Marmoutier (Tours, Indreet-Loire), Rapport 2013, 2 vols. (2013). Retrieved on 4 October 2015: citeres.univ-tours.fr/ spip.php?article1305.

Lorans, Élisabeth and Thomas Creissen (eds.), Le site de l'abbaye de Marmoutier (Tours, Indreet-Loire), Rapport 2014, 2 vols. (2015). Retrieved on 19 May 2016: citeres.univ-tours.fr/ spip.php?article1305. 
Lorans, Élisabeth and Thomas Creissen (eds.), Le site de l'abbaye de Marmoutier (Tours, Indreet-Loire), Rapport 2015, 2 vols. (2015). Retrieved on 19 May 2016: citeres.univ-tours.fr/ spip.php?article1305.

Lorans, Élisabeth and Thomas Creissen (eds.), Le site de l'abbaye de Marmoutier (Tours, Indre-et-Loire), Rapport 2016, 2 vols. (2016). Retrieved on 07 December 2018: citeres.univtours.fr/spip.php?article1305.

Lorans, Élisabeth and Thomas Creissen (eds.), Le site de l'abbaye de Marmoutier (Tours, Indreet-Loire), Rapport 2017, 2 vols. (2017). Retrieved on 07 December 2018: citeres.univ-tours. fr/spip.php?article1305.

Lorans, Élisabeth and Thomas Creissen (eds.), Le site de l'abbaye de Marmoutier (Tours, Indreet-Loire), Rapport 2015-2017 (2017). Retrieved on 07 December 2018: citeres.univ-tours. fr/spip.php?article1305.

Lorans, Élisabeth and Gaël Simon, Autour de Marmoutier: Les premiers siècles du monachisme en Touraine, in: Sébastien Bully (ed.), Construire l'Europe: Colomban et son héritage, Actes du Colloque de Luxeuil (16-20 septembre 2015) (Rennes, 2018) 87-106.

Markus, Robert A., The End of Ancient Christianity (Cambridge, 1990).

Martine, François, Vie des Pères du Jura, SC 142 (Paris, 2004).

Masai, François, La »Vita patrum iurensium« et les débuts du monachisme à Saint-Maurice d'Agaune, in: Johanne Autenrieth and Franz Brunhölzl (eds.), Festschrift Bernhard Bischoff zu seinem 65. Geburtstag dargebracht von Freunden, Kollegen und Schülern (Stuttgart, 1971) 43-69.

Mordefroid, Jean-Luc, Quel désert pour les Pères du Jura? Résultats du sondage archéologique effectué dans la cathédrale en avril 1990, in: Pierre Lacroix, Andrée Renon, Marie-Claude Mary and Éliane Vergnolle (eds.), Pensée, image et communication en Europe médiévale: $A$ propos des stalles de Saint-Claude, Colloque international, Saint-Claude, Lons-le-Saunier, 2426 septembre 1990 (Besançon, 1993) 3-10.

Moyse, Gérard, Les origines du monachisme dans le diocèse de Besançon (Ve-Xe siècles), Bibliothèque de l'École des Chartes 131 (1973) 21-104.

Natal, David, "A Suitable Successor«: Building Legitimacy in Hilary's Sermon on the Life of Honoratus, Reti medievali 16 (2015) 147-168.

Nouailhat, René, Saints et patrons: Les premiers moines de Lérins, Centre de Recherches d'Histoire Ancienne 84, Annales Littéraires de l’Université de Besançon 382 (Paris, 1988).

Pietri, Luce and Marc Heijmans (eds.), Prosopographie chrétienne du Bas-Empire: La Gaule chrétienne (314-614), 2 vols (Paris, 2013).

Pliny, Naturalis historia, vol. 2, trans. Harris Rackham, Pliny. Natural History, LCL 352 (Cambridge, MA, 1989).

Pricoco, Salvatore, Eucherio. Elogio dell'eremo, Biblioteca Patristica (Bologna, 2014).

Pricoco, Salvatore, L'isola dei santi: Il cenobio di Lerino e le origini del monachesimo gallico, Filologia e Critica 23 (Rome, 1978).

Quacquarelli, Antonio, Lavoro e ascesi nel monachesimo prebenedettino del IV e V secolo, Quaderni di »Vetera Christianorum« 18 (Bari, 1982).

Rapp, Claudia, Desert, city, and countryside in the early Christian imagination, Church History and Religious Culture 86 (2006) 93-112.

Regula quattuor patrum, ed. Adalbert de Vogüé, Les Règles des saints Pères, vol. 1: Trois Règles de Lérins au Ve siècle, SC 297 (Paris, 1982) 180-205.

Rothé, Marie-Pierre, Carte archéologique de la Gaule, vol. 39: Le Jura (Paris, 2001). 
Rousseau, Philip, Cassian: Monastery and world, in: Miles Fairburn and W. H. Oliver (eds.), The Certainty of Doubt: Tributes to Peter Munz (Wellington, 1996) 68-89.

Secunda regula patrum, ed. Adalbert de Vogüé, Les Règles des saints Pères, vol. 1: Trois Règles de Lérins au Ve siècle, SC 297 (Paris, 1982) 274-283.

Sidonius Apollinaris, Epistulae, ed. André Loyen, Sidoine Apollinaire, vol. 2: Correspondance, Livres I-V, Collection des Universités de France (Paris, 2003).

Stancliffe, Clare, St. Martin and His Hagiographer: History and Miracle in Sulpicius Severus (Oxford, 1983).

Strabo, Geographikon, vol. 2, trans. Horace Leonard Jones, The Geography of Strabo, LCL 50 (Cambridge, MA, 1988).

Sulpicius Severus, Chronica, ed. Ghislaine de Senneville-Grave, Sulpice Sévère. Chroniques, SC 441 (Paris, 1999).

Sulpicius Severus, Dialogi, ed. Jacques Fontaine and Nicole Dupré, Sulpice Sévère. Gallus: Dialogues sur les "vertus" de Saint Martin, SC 510 (Paris, 2006); English trans. Alexander Roberts, The Dialogues of Sulpitius Severus, A Select Library of Nicene and Post-Nicene Fathers of the Christian Church, second series 11 (New York, 1894) 24-54.

Sulpicius Severus, Vita sancti Martini, ed. Jacques Fontaine, Sulpice Sévère. Vie de Saint Martin, SC 133, 1 (Paris, 1967) 247-317; English trans. Alexander Roberts, Sulpitius Severus on the Life of St. Martin, A Select Library of Nicene and Post-Nicene Fathers of the Christian Church, second series 11 (New York, 1894) 3-17.

Vita patrum iurensium, ed. François Martine, Vie des Pères du Jura, SC 142 (Paris, 2004); English trans. Tim Vivian, Kim Vivian, and Jeffrey Burton Russell, The Life of the Jura Fathers (Kalamazoo, 1999).

Vita sancti Lupi episcopi, ed. Bruno Krusch, MGH, SRM 7 (Hanover, 1920) 295-302.

Vivian, Tim, Kim Vivian and Jeffrey Burton Russell, The Lives of the Jura Fathers (Kalamazoo, 1999).

De Vogüé, Adalbert, Histoire littéraire du mouvement monastique dans l'Antiquité, vol. 4: Sulpice Sévère et Paulin de Nole (393-409), Jérôme, homéliste et traducteur des »Pachomiana" (Paris, 1997).

De Vogüé, Adalbert, Histoire littéraire du mouvement monastique dans l'Antiquité, vol. 7: L'essor de la littérature lérinienne et les écrits contemporains (410-500) (Paris, 2003).

De Vogüé, Adalbert, Histoire littéraire du mouvement monastique dans l'Antiquité, vol. 8: De la Vie des Pères du Jura aux ouvres de Césaire d'Arles (500-542) (Paris, 2003).

De Vogüé, Adalbert, Les Règles des saints Pères, vol. 1: Trois Règles de Lérins au Ve siècle, SC 297 (Paris, 1982).

Wickham, Chris, Framing the Early Middle Ages: Europe and the Mediterranean, 400-80o (Oxford, 2006).

Wipszycka, Ewa, Les aspects économiques de la vie de la communauté des Kellia, in: Philippe Bridel (ed.), Le site monastique des Kellia: Sources historiques et explorations archéologiques (Geneva, 1986) 117-144. Reprinted in: Ewa Wipszycka, Études sur le christianisme dans l'Égypte de l'Antiquité tardive, Studia Ephemeridis Augustinianum 52 (Rome, 1996) 337362.

Wood, Ian, A prelude to Columbanus: The monastic achievement in the Burgundian territories, in: Henry B. Clarke and Mary Brennan (eds.), Columbanus and Merovingian Monasticism, BAR International Series 113 (Oxford, 1981) 3-32. 